\title{
Microwaving human faecal sludge as a viable sanitation technology option for treatment and value recovery - a critical review
}

\section{Authors}

- Oluwasola O.D. Afolabi

- M. Sohail

\section{Affiliations}

School of Civil and Building Engineering, Loughborough University

Loughborough, LE11 3TU, UK

\section{* Corresponding author}

E-mail address: o.o.d.afolabi2@,lboro.ac.uk 


\section{Abstract}

The prolonged challenges and terrible consequences of poor sanitation, especially in developing economies, call for the exploration of new sustainable sanitation technologies. Such technologies must be: capable of effectively treating human faecal wastes without any health or environmental impacts; scalable to address rapid increases in population and urbanization; capable of meeting environmental regulations and standards for faecal management; and competitive with existing strategies. Further and importantly, despite its noxiousness and pathogenic load, the chemical composition of human faecal sludge indicates that it could be considered a potentially valuable, nutrient-rich renewable resource, rather than a problematic waste product. New approaches to faecal sludge management must consequently seek to incorporate a 'valuable resource recovery' approach, compatible with stringent treatment requirements.

This review intends to advance the understanding of human faecal sludge as a sustainable organic-rich resource that is typically high in moisture (up to 97 per cent), making it a suitable candidate for dielectric heating, i.e. microwave irradiation, to promote faecal treatment, while also recovering value-added products such as ammonia liquor concentrate (suitable for fertilizers) and chars (suitable for fuel) - which can provide an economic base to sustain the technology. Additionally, microwaving human faecal sludge represents a thermally effective approach that can destroy pathogens, eradicate the foul odour associated human faecal sludge, while also preventing hazardous product formations and/or emissions, aside from other benefits such as improved dewaterability and heavy metals recovery. Key technological parameters crucial for scaling the technology as a complementary solution to the challenges of onsite sanitation are also discussed.

\section{Keywords}

Human faecal sludge, microwave, sanitation, waste management, resource recovery, low- and middle-income countries 


\title{
1. Introduction
}

Despite numerous longstanding international programmes and complementary strategies aimed at addressing poor sanitation in at-risk countries, the statistics for people without improved sanitation facilities and the associated health risks and effects are still alarming: 2.4 billion people currently lack access to improved sanitation facilities, while 1.1 billion still practice open defecation (WHO/UNICEF, 2015) (see Fig. 1).

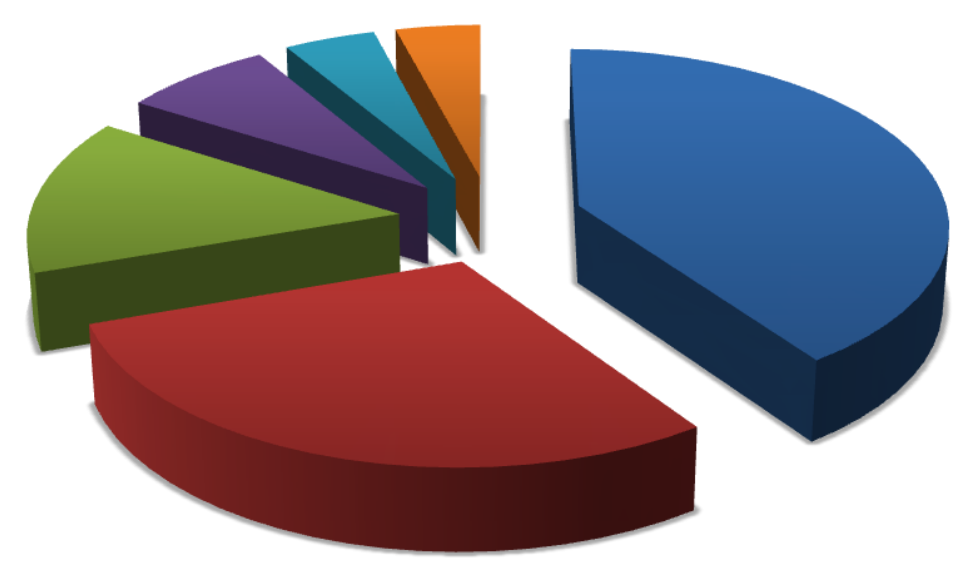

\author{
- Southern Asia, 953 \\ Sub-Saharan Africa, 695 \\ Eastern Asia, 337 \\ - South-Eastern Asia, 176 \\ Latin America and the \\ Carribean, 106 \\ Other regions, 98
}

Fig. 1. Global distribution of people (numbers in millions by region) without access to improved sanitation facilities in 2015 [Source: WHO/UNICEF, 2015]

The consequences are devastating: poor sanitation and contaminated drinking water resources cause more than 80 per cent of all disease in the developing world (WHO, 2003; CDC, 2011). An estimated 1.8 billion people consume faecal-contaminated water, and this increases the health risk of water-borne diseases - such as diarrhoea - which kill 700,000 infants per year (UNICEFIGME, 2012). Apart from the health impacts, poor sanitation also has pervasive societal effects, such as increasing the rate of school drop-outs for young women and girls who cannot attend school without the adequate sanitation facilities they need to manage their personal hygiene during menstruation (WHO/UNICEF, 2004). Furthermore, nursing the sick that contract diseases due to poor sanitation adds an additional financial strain on many already living below the US $\$ 1.25$ per day poverty line, while also reducing their ability to earn incomes, thereby encouraging a cycle of continuous poverty. 
Apart from the non-technical issues - such as lack of a regulatory framework, sanitation-related institutions, capacities and financial constraints - most approaches to onsite sanitation in economically disadvantaged regions may be viewed as being labour intensive, crude and ineffective. Such approaches fail to address basic structural, environmental and ecological needs (Eckhoff and Wood, 2011). Currently, open defecation and manually emptying of human faecal sludge (HFS) slurry-pits, with the accompanying pumping, draining, storage, transportation and disposal, is still a widespread practice. Such activities create hazardous exposure to pathogens for all concerned, and often lead to uncontrolled and indiscriminate disposal into drains, canals and open places, especially in developing countries. Indiscriminate disposal sometimes take place near points of (water) abstraction or near slums and shantytowns of economically deprived communities due to poor road networks, traffic congestion and a lack of properly managed dumps/landfill sites (Strauss and Montangero, 2002). Such practices further aggravate the health impacts of exposure to untreated HFS and pollution of the environment. For millions of people across the developing world, restricted access to adequate sanitation, hygiene and potable water affects their nutritional status, health and quality of life, and is ultimately reflected in the reduced life expectancies characteristic of communities that are impacted in this way.

The effects of poor sanitation demand the introduction of complementary approaches, which should be strategically positioned to resolve current impacts and mitigate those induced by increasing urbanization and populations. Such approaches need to embody effective, affordable and sustainable technologies, which can substitute/complement current approaches to onsite sanitation. A review of existing technologies, such as the widely used biological processes and incineration, finds that they are difficult to implement in dispersed rural settlements and poorly developed urban settings with high occupation rates (slums). Large construction footprints, long conversion times, greenhouse gas emissions, along with air pollutants, all raise further barriers to their transfer/adoption in economically deprived areas. Consequently, there is an enduring need to develop better technologies, or remodel and optimize existing ones that are sustainable and effective in managing human faecal sludge. Most importantly, such developments must be viable and able to be scaled to meet the needs of an increasing population that is undergoing rapid urbanization.

Furthermore and also importantly, a large proportion of the nutrients in food consumed are present in urine and faeces, and hence HFS contains valuable resources that include, but are not limited to: water, nutrients, urea, minerals, salts and energy. Two primary components that can be viably recovered from HFS are plant nutrients (primarily nitrogen $[\mathrm{N}]$, phosphorus $[\mathrm{P}]$, potassium $[\mathrm{K}]$ ) and energy [carbon, $\mathrm{C}]$ ). Nevertheless, the pathogenic content of HFS presents a 
serious challenge, both for treatment and resource-recovery purposes. Additionally, HFS may also contain residues of many complex engineered chemicals/synthetic products - hormones, antibiotics and food additives, for example. Some of these compounds pose further environmental risks due to their poor biodegradability. The challenge, therefore, is to develop novel technological ways and means necessary to provide safe and affordable sanitation to 2.4 billion people in a manner that is pleasing to use, publically acceptable and that effectively removes human waste from the environment, while also recovering recyclable valuables from it. Ideally, this is to be achieved without additional financial burden or the need for piped water or sewerage systems, which are not present/readily available in regions affected by poor sanitation. This need forms the basis for this review, which seeks to:

- illustrate HFS as a 'resourceful material that can be beneficially exploited for the realization of its intrinsic value (to provide energy and plant fertilizer, for instance);

- advance the knowledge of microwave suitability as an alternative sanitation technology for processing HFS - to convert it into a safe, pathogen-free material, while also recovering inherent value; and

- enumerate parameters and other related factors crucial for the scaling of the technology for onsite sanitation/ faecal management purposes.

\section{Human faecal sludge characterization}

HFS, in the context of onsite sanitation, generally encompasses the slurry/semi-solids mixture of fresh, unprocessed or partially digested excreta (a mixture of urine and faeces only), along with associated sanitary cleansing products typically found at and in sanitation facilities such as pit latrines, wash blocks, mobile toilets, septic tanks, aqua privies, dry toilets and open-defecation sites. It may also contain blackwater, with or without greywater; and makes up the largest amount of bodily waste generated daily (Franceys et al, 1992). HFS is highly heterogeneous and variable in content, consistency, quantity, composition and concentration (Hemkend-reis et al, 2008). Fig. 2 shows the characteristic composition of HFS. It is characterized as a complex mixture of water; pathogenic microorganisms (viruses, bacteria, helminths and protozoa); nutrients in the form of undigested macromolecular organics (i.e. protein, lipids and polysaccharides); and inorganics, ash and minerals (Franceys et al, 1992; Putman, 1971; Wignarajah et al, 2006). The presence of exogenous compounds, including radioisotopes, antibiotics, food additives and heavy metals, has also been reported in HFS (Schouwa et al, 2002; Titley et al, 2000; Vinnerås et al, 2006). 
Fresh HFS is typically brown in colour and tends towards dark brown, depending on length of storage. The Bristol Stool Chart described by Heaton and Lewis (1997), which ranges from Type 1 through to Type 7, is widely used as a linear scale to characterize the texture, forms and variation of HFS based on visual appearance. Foul odour characterizes HFS due to the presence of nitrogenous benzopyrrole compounds, notably indole and skatole, hydrogen sulphides, methyl sulphides and other sulphur-containing compounds (Moore et al, 1987; Sato et al, 2002). This has an instantaneous, unpleasant impact, causing considerable distress to the public and workers, especially during handling, storage and/or transportation. While the toxicological effects of foul odours associated with HFS are yet to be proved, there have been reported cases of illness/symptoms associated with exposure to malodorous sludges (Chrostowki, and Foster, 2003; Cain, and Cometto-Muniz, 2004).

The moisture content in human faeces is between 63 and 86 per cent w/w (Rose et al., 2015), while urine is mainly composed of water: between 93 and 96 per cent w/w (Polprasert, 1995). The addition of flush water, anal cleansing water and/or other sanitary products affects the moisture-to-total solids loading in resultant HFS. Up to 97 per cent moisture content - similar to those obtained in primary sewage sludge (commonly used as surrogate for faecal sludge for treatment purposes) - has been reported in HFS (Heinss et al, 1998; Tchobanoglous et al, 2003; Niwagaba et al, 2014). The $\mathrm{pH}$ of faecal sludge water generally ranges between 5.0 and 9.3 (Mai et al, 2009; Kengne et al 2011), influenced by dietary fibre in faecal matter (Newark and Lupton, 1990) and potentially by composition of sanitary products and the buffering effects of urine and flush water.

Untreated HFS is hazardous due to the potential presence of pathogenic bacteria, viruses, parasitic protozoa and helminthic nematodes. It is the faecal matter in HFS that contains most of these pathogens, as urine from healthy humans is generally sterile (WHO, 2006). Human faeces may contain a pathogenic load in the range $10^{5}-10^{10}$ faecal coliforms per $100 \mathrm{ml}$ (Von Spelling, 2007) and up to 60,000/L of helminth eggs (Heinss et al, 1998). To enable safe handling and reuse of treated HFS value-added products, the levels of E.coli and/or helminth eggs in treated HFS are used as health/safety pathogenic indicators. These must be: for E.coli (number per $100 \mathrm{ml}$ of treated waste) $<1000 / \mathrm{g}$ total solids, while for helminth eggs (number per gram total solids or per litre) $<1 /$ g total solids (WHO, 2006).

Analyses of faecal solids reveal they are composed of 84-93 per cent organics, with the remainder as inorganics fractions (Feachem et al, 1978; Nwaneri et al, 2008; Bai and Wang, 2011). The inorganics are composed mainly of phosphates of calcium, iron and internal organs' 
secretions (Guyton and Hall, 2000), while the organic fraction is composed of bacteria debris, typically 10-30 per cent (Ganong, 1983; Wignarajah et al, 2006) and up to 54 per cent (Stephen, and Cummings, 1980); and undigested protein - between 2 and 25 per cent, with up 50 per cent contribution from dead bacteria debris (Canfield et al, 1963; Volk and Rummel, 1987). Undigested fats are in the range 2-15 per cent (Kien et al, 1981; Chen et al, 1998; Wierdsma et al, 2011) and up to 25 per cent (Wignarajah et al, 2006); carbohydrates 10-30 per cent (Ganong, 1983); and minerals - mainly calcium (Ca), potassium, $(\mathrm{K})$ and phosphorus $(\mathrm{P})$ - in the range 5-8 per cent (Wignarajah et al, 2006).

These percentage weight distributions are largely affected by diet. Undigested proteins in faecal matter are mainly nitrogenous compounds from bacteria biota, nucleic acids and mucus secreted from intestinal walls (Bender and Bender, 1997). Fatty acids, waxes and phosphoglycerides make up the fat content in faecal matter, and are derived from undigested dietary fat intake, bacteria and fat in shredded epithelial cells (Guyton and Hall, 2000; Rose et al, 2015), while faecal carbohydrates are mainly composed of undigested cellulose, fibres and pentosan (Canfield et al, 1963). Undigested fibres make up to 25 per cent of the carbohydrates fraction (Volk and Rummel, 1987). Organics in urine solids range from 65 to 85 per cent (Strauss, 1985) and are predominantly composed of urea (Putman, 1971). The urine liquid fraction is composed mainly of water, organic acids (uric acid, citric acids), electrolytes, solubilized metabolites, hormones, vitamins, ammonium salts, nitrogenous compounds and inorganic salts (Putman, 1971; Polprasert, 1995).

Elemental characterization of dried faecal matter fraction in HFS reveals it is composed of 4.5 per cent Ca; 3-5.4 per cent P and 1-2.5 per cent K (Feachem et al, 1978), while dried urine is composed of 14-18 per cent N; 13 per cent C; 3.1 per cent $P$ and 3.7 per cent K (Strauss, 1985). Faecal fractions generally contain more heavy metals, including zinc $(\mathrm{Zn})$, copper $(\mathrm{Cu})$, nickel (Ni), cadmium (Cd), lead $(\mathrm{Pb})$ and mercury (Hg) (Schouwa et al, 2002). Generally, the concentrations of heavy metals reportedly found in faecal sludge from different studies are relatively low and in most cases less than $2 \mathrm{mg} / \mathrm{cap} /$ day - with the exception of $\mathrm{Zn}$, which can be up to 16mg/cap/day (Hansen and Tjell, 1979; Eastwood et al, 1984; Schouwa et al, 2002; Vinnerås et al, 2006).

Generation rates of HFS vary largely and depend on many factors such as gender, age, occupation, geographical location and climate, body weight, dietary intake and water consumption (Franceys et al, 1992; Rose et al, 2015). Direct measurement is primarily employed in studies to estimate generation rates. These find a range of $130-520 \mathrm{~g} / \mathrm{cap} /$ day of faeces 
generated in developing countries and 100-200g/cap/day for European and North American countries (Feachem et al, 1983). Differences in generation rates across the regions concerned are largely due to the nature of diet, as developing countries consume a more fibre-based diet, while and European and North American countries consume a more protein-based diet (Franceys et al, 1992; Wignarajah et al, 2006; Eastwood et al, 1984). The amount of urine generated is also largely dependent on the water consumption rate, temperature and humidity defining the geographical location considered. Generally, urine-generation rates range between 0.6 and 2.1 L/cap/day (Wydeven and Golub 1991; Del Porto and Steinfeld, 1999; Schouwa et al, 2002). Additionally, stooling rates/frequency of urination, waste streams due to sanitary products, and water inputs due to flushing and/or anal cleansing (which are largely dependent on occupation and behavioural practises) affect daily generation rates for HFS. Generation rates of these additional wastes streams are also summarized in Fig. 2. For faecal treatment design purposes, one review recommended an average of $128 \mathrm{~g} / \mathrm{cap} /$ day and $1.42 \mathrm{~L} / \mathrm{cap} /$ day of faecal and urine generation rates (Rose et al, 2015), as use of flush water volume and other sanitary-related products could be managed or controlled. 
Fig. 2. Characteristic composition of HFS (extracted from Heinss et al, 1998; Schouwa et al, 2002; Wignarajah et al, 2006; Niwagaba et al, 2014;

Rose et al, 2015)

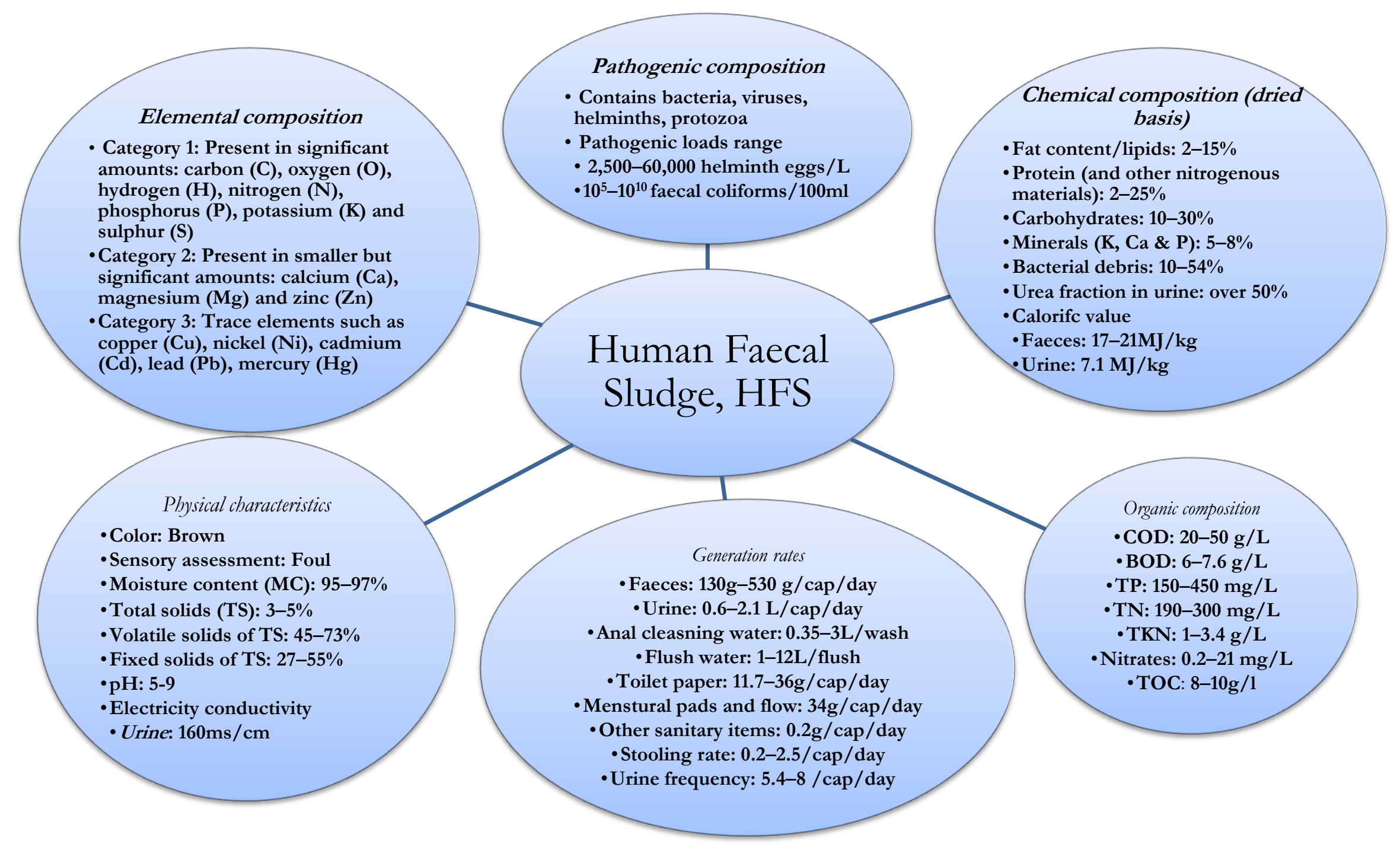


HFS has been explored extensively for agricultural use (Cofie et al, 2005; Cofie et al, 2006; Yadav et al, 2010). Consider, for example, Terra preta do Indio, also called Amazonian Dark Earth (ADE) - highly fertile and productive black soils found in the Amazon Basin region, which are reported to result from the prolonged use of soil ameliorants derived from human waste (Lehmann et al, 2003; Yoshida and Antal, 2009). Direct excretion of urine and faeces onto agricultural land in Thailand to supplement fertility has also been reported (Schouwa et al, 2002). At the same time, the direct application of urine for horticulture is a common practise that, in Nepal, has been scaled up so that diverted urine stored in urine banks may be either applied directly to soil, used in aquaculture or used to produce struvite (a phosphorous-rich, powdery compound derived from the addition of magnesium to urine banks), which is subsequently applied as fertilizer (Etter et al, 2011).

Essentially the key plant nutrients in HFS that are vital from the resource-recovery perspective are nitrogen $(\mathrm{N})$, phosphorus $(\mathrm{P})$ and potassium $(\mathrm{K})$. Table 1 provides ranges of daily generation rates of nutrients recoverable from the urine and faecal components of HFS. Of the faecal and urine fractions of HFS, urine contains the largest amount of $\mathrm{N}$ ( 90 per cent); P (50-65 per cent) and K (50-80 per cent) (Heinonen-Tanski and van Wijk-Sijbesma, 2005). P and K in urine are excreted in ionic forms and in plant-available forms that are the same as those found in chemical fertilizers (Kirchmann and Pettersson 1995). Studies conducted in Sweden indicate that on an yearly basis nutrients recoverable per capita in urine are: $2.5-4.3 \mathrm{~kg} \mathrm{~N}, 0.4-1.0 \mathrm{~kg} \mathrm{P}$ and $0.9-1.0 \mathrm{~kg}$ $\mathrm{K}$, while those in the faecal component are: $550 \mathrm{~g} \mathrm{~N}, 183 \mathrm{~g} \mathrm{P}$ and $365 \mathrm{~g} \mathrm{~K}$ (Lentner and Wink, 1981; Jonsson et al, 2005; Vinnerås et al, 2006). This means the plant nutrients in the urine and faecal components add up to $4.8 \mathrm{~kg} \mathrm{~N}, 1.1 \mathrm{~kg} \mathrm{P}$ and $1.4 \mathrm{~kg} \mathrm{~K}$ per capita per year (Jonsson et al, 2005; Vinnerås et al, 2006); this is enough to meet the fertilizer requirements for about a quarter ton of cereal, for example (Drangert, 1998). 
Table 1 Daily generation loading of key plant nutrients in HFS

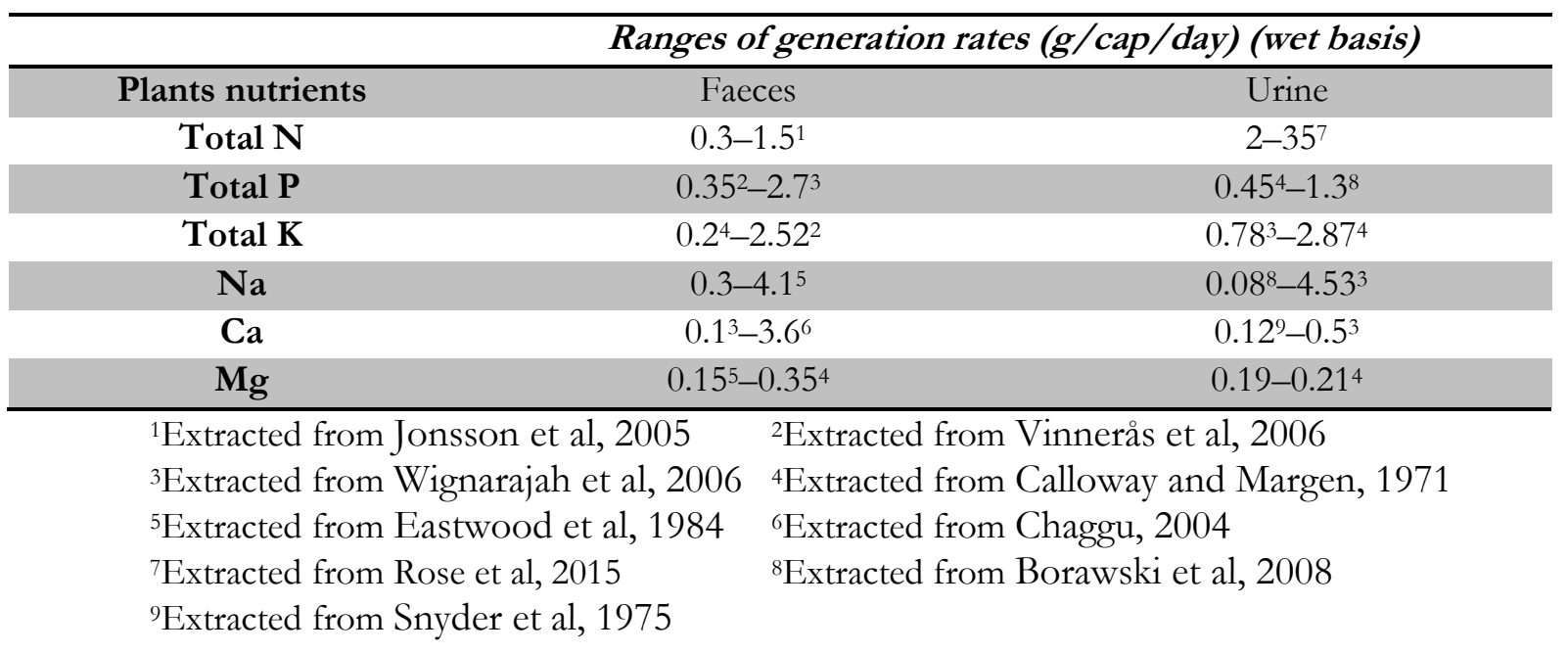

From an energy-recovery perspective, recovery of constituent carbon (C) in HFS is essential. Faecal and urine components of HFS contain 44-55 per cent and 11-17 per cent $C$ respectively (Feachem et al, 1978; Strauss, 1985). More than 7g/cap can be recovered based on daily loadings estimation (Snyder et al, 1975). Similarly, the volatile solids, which provide an indication of combustibility, range between 75 and 85 per cent in urine and up to 92 per cent in faeces (Fry and Merrill, 1973). When combined in HFS, however, this figure ranges between 45 and 73 per cent (Niwagaba et al, 2014).

Carbon content in any material correlates with its calorific value. The use of bomb calorimeters, proximate analysis (volatile matter, fixed solids and moisture content determination by standard procedure) or elemental analyses (determination of carbon, hydrogen and nitrogen contents) of materials are sometimes used to predict the amount of energy that can be recovered from such material (Cordero et al, 2001; Friedl et al, 2005). Based on these, one study predicted the average calorific value of dried urine and dried faeces to be $7.1 \mathrm{MJ} / \mathrm{kg}$ and $17 \mathrm{MJ} / \mathrm{kg}$ respectively (Rose et al, 2015). Another reported the calorific values of faecal sludge in three African countries to range between 16 and 19MJ/kg (Muspratt et al, 2014). For biogas recovery through anaerobic digestion, for example, or for other related biofuels recovery, chemical oxygen demand (COD) values of HFS, which range between 20 and 50g/L (Niwagaba et al, 2014) at 1.6kg/cap/day (Vinnerås et al, 2006), suggest they can be suitable substrates. However, direct use of HFS for anaerobic digestion is not recommended and requires careful consideration, as the levels of ammonia, organics (urea for example), heavy metals and sulphides present in HFS are key 
inhibitors of principal microorganisms (methanogens in particular) of the anaerobic digestion process (Chen et al, 2008).

In essence, a good percentage of diet consumed is locked as an energy resource and plant nutrients in HFS. Using an appropriate technological technique - like the microwave processing reviewed in this paper - these resources/nutrients can be beneficially recovered for other applications, without any of the health risks or environmental impacts that hamper their direct use.

\subsection{Case for novel technological integration with onsite sanitation systems}

From a health perspective, direct use or exposure to untreated HFS is always hazardous (due to its pathogenic load) and represents a risk to public health. Any treatment method must address such risks and conform to World Health Organization (WHO) guidelines on E.coli and helminth eggs, due to their prevalence in both onsite sanitation and conventional wastewater treatment facilities and their propensity to end up in the biosolids generated by wastewater treatment (WHO, 2006). Over the years, few onsite sanitation solutions used in developing countries have comprehensively addressed pathogen kill and odour eradication while treating HFS. Composting, for example, is characterized by significant pathogenic residues due to the low temperatures $\left(<50^{\circ} \mathrm{C}\right)$ involved (Schoenning and Stenstroem, 2004; Spuhler, 2011). Direct exposure to faecal matter during the composting process also represents a health risk. Other biological processes such as settling tank/sedimentation beds, unplanted natural air-drying beds and wetlands - are ineffective, as they also cannot generate pathogen-free stabilized biosolids. Odour nuisance, parasitic helminths (which tend to concentrate in settled or floating solids (Jimenez, 2007)) and E. coli, for example, characterize the end products of these processes (WHO, 2006). Anaerobic digestion technologies require significant construction investments, can take up to three weeks to process human waste and still do not ensure complete pathogen destruction. The highest temperature range of anaerobic digestion, i.e. the thermophilic range, is $45-60^{\circ} \mathrm{C}$ (Demirbas et al, 2011); this is too low for pathogenic inactivation. Freeze/thawing technology, which damages pathogenic cells via intracellular freezing and osmotic effects (Mazur, 1986), has recorded little success in terms of pathogen deactivation, as thawed sludge falls short of WHO treatment standards (Sanin et al, 1994). Also, the process is highly selective and while economic for poor cold regions, is impractical for regions characterized by relatively high ambient temperatures. The process additionally requires high-energy inputs due to the inevitable low temperature 
requirement for freezing. Thermal treatment, such as incineration, is capital intensive and generates dioxins and other toxic air pollutants, which pose risks to public health (US EPA, 2003; Rulkens, 2008). Furthermore, such processes are limited to dry substrate as the starting material, requiring high-energy inputs with significant greenhouse gas emissions (Demirbas et al, 2011). Other technologies such as ultrasonication (Show et al, 2007), hydrodynamic cavitation (Lee and Han, 2013); mechanical treatment (Nah et al, 2000); oxidation by ozone (Yeom et al, 2002); alkali pretreatment (Mouneimne et al, 2003); or a combination of technologies (Barienbruch and Kopplow, 2003; Eskicioglu et al, 2008b; Zupanc et al, 2013; Yeneneh et al, 2015; Doğruel, and \& Özgen, 2016) have also been reported. While most of these technologies have been extensively explored as sludge pre-treatment processes, their potential use and/or integration into onsite sanitation systems is still evolving.

In summary, most of these current approaches are difficult to implement in dispersed rural settlements and poorly developed urban settings with high-occupation rates (slums). The large construction footprints, long conversion times, greenhouse gas emissions, along with air pollutants, all raise further barriers to their transfer/adoption in economically deprived areas. Consequently, there is an enduring need to develop better technologies, or to remodel and optimize existing ones that are sustainable and effective at managing HFS. Such developments must be viable for adoption and transfer in low- and middle-income countries.

\section{The microwave technology}

Microwave technology is an acknowledged and widely accepted heating source, and has been used for diverse applications. Developed primarily for communications and some areas of food processing, microwaves are now extensively explored for digestion of environmental samples into ionic forms for quantitative analyses (Islam, and Weil, 1998); and accelerated synthesis of materials to generate and produce new and valuable intermediates/compounds, and nanostructure materials with special functionalities (Ifrah et al, 2007; Zhenyu et al, 2007; Hu et al, 2009; Wang et al, 2011). This technology has also been used to recover valuable gaseous hydrocarbons from dried sewage sludge (Menendez et al, 2002; Sobhy and Chaouki, 2010). The feasibility of microwave technology to achieve these results has been attributed to its characteristic potential to selectively heat materials and alter (suppress and/or activate novel) reaction pathways, and accelerate overall reaction rates through the induction of rapid volumetric heating at the molecular level (Clark et al, 2000; Sobhy and Chaouki, 2010). The net effects of 
this include reduction on processing times, energy and associated costs. Microwave irradiation also has the capacity to diminish hazardous product formation and prevent emission of fugitive or greenhouse gases, hence making it environmentally friendly.

In essence, microwave technology has significant potential as a viable and efficient heating source for the treatment and valorization of bio-based wastes/materials such as HFS. Furthermore and most importantly, technological familiarization and established public acceptance of microwave technology as a domestic (homes and offices) and industrial appliance, both in developed and developing regions, may promote its adoption and transfer into existing onsite sanitation systems - either as a standalone unit or integrated with a network of decentralized systems. Despite its potential, however, knowledge or application of this technology for treating and processing human excreta or $\mathrm{HFS}^{1}$ for onsite sanitation is largely non-existent. This review partly intends to drive interest in the potential of microwave technology for processing HFS at household, small networked decentralized onsite sanitation systems and other related facilities, and as a technological option that can be used for mobile processing of HFS.

\subsection{Principles of the microwave technology}

Within the electromagnetic spectrum, microwaves are non-ionizing radiation that occupy the wavelengths from $1 \mathrm{~mm}$ to $1 \mathrm{~m}$, with a corresponding frequency range of $0.3 \mathrm{GHz}-300 \mathrm{GHz}$ (Shuntaro and Jun-Ichi, 2011). Microwave heating applied for industrial, medical and scientific applications use mainly two microwave frequencies, $0.915 \mathrm{GHz}$ and $2.45 \mathrm{GHz}$ (Bradshaw et al, 1998). Domestic ovens, for example, use the $2.45 \mathrm{GHz}$ frequency to heat. At this frequency, the energy of the microwave photon is $0.0016 \mathrm{eV}$; this is too low to break chemical bonds such as $\mathrm{H}$ $\mathrm{OH}$, which is $5.2 \mathrm{eV}$, and hence cannot ionize human living tissue, as compared with the $\sim 33 \mathrm{eV}$ energy released per ionization radiation of x-rays/gamma rays (Kappe, 2004; Yin, 2012). This means microwaves are not ionizing radiation, cannot induce chemical reactions and nor can they affect users of the technology within necessary safety limits.

\footnotetext{
1 This does not apply to primary sewage sludge obtained in wastewater treatment plants, as this is different in form and physicochemical compositions to fresh human excreta or HFS in that it has undergone significant decomposition and degradation during transit in sewers, and may contain non-domestic waste streams. However, this doesn't preclude microwave suitability for primary sewage sludge treatment or valorization.
} 
Microwave systems have three main integrated features: microwave generation, transmission and application (See Fig. 3). Microwaves are usually generated in a vacuum tube, commonly referred to as a magnetron or a magnetron tube, and coupled for transmission through a waveguide (hollow tubes) to the point of application via microwave (single/multi-mode cavities) applicators (Thostenson and Chou, 1999). For heat to be generated within a material by microwaves, it must be partially transparent to microwave radiation while absorbing the microwave energy. The ability of a material to absorb microwave energy is governed by its dielectric properties: dielectric constant $\left(\varepsilon^{\prime}\right)$ and dielectric loss $\left(\varepsilon^{\prime \prime}\right)$. The dielectric constant quantifies its capacitive property (i.e. the ability of the dipolar molecule of the material to be polarized by an electric field), while dielectric loss reflects its conductive ability (i.e. the efficiency of converting incident microwave energy to heat within the material) (Bradshaw et al, 1998; Thostenson and Chou, 1999). Both properties are related by the complex dielectric constant $\left(\varepsilon^{*}\right)$; this is used to describe the total dielectric properties of any material and is expressed as:

$$
\varepsilon^{*}=\varepsilon^{\prime} \pm j \varepsilon^{\prime \prime} \quad \text { Equation } 1
$$

Where the real part, $\varepsilon^{\prime}$, represents the ability of the material to be polarized by an external electric field; and the imaginary part, $j \varepsilon^{\prime \prime}$, is the effective loss which quantifies the efficiency with which the microwave energy is converted to heat (Venkatesh and Raghavan, 2004).

\section{Electromagnet}

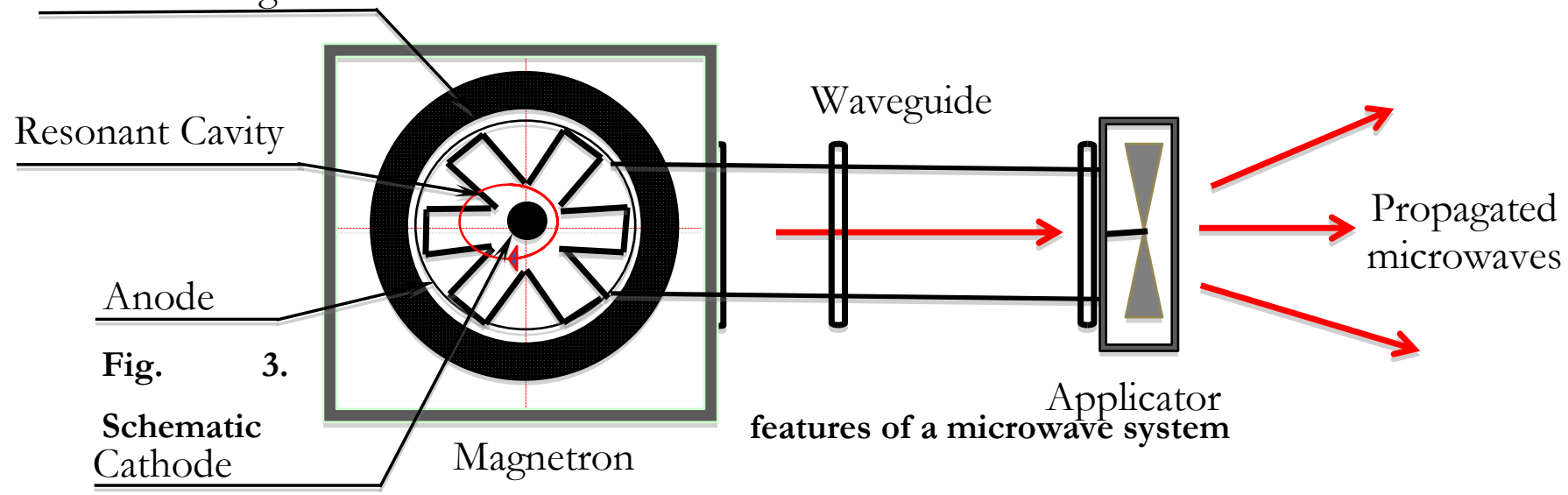

Tangent loss, \begin{tabular}{|l|l|l|} 
Generation & Transmission & Application \\
\hline
\end{tabular} also called the dissipation factor of materials, $\tan \delta$, is the ratio of the dielectric loss, $\varepsilon^{\prime \prime}$, of heated material to its dielectric constant, $\varepsilon^{\prime}$. Tan $\delta$ reflects the dielectric response of any 
materials and is used to describe the overall efficiency of any material to absorb microwave energy and convert it to heat at a specific frequency (Clark et al, 2000). It is used to characterize the microwave-absorbing potentials of materials such as: transparent/insulators (i.e. materials not sensitive to microwave energy, as it can pass through with little or no attenuation, e.g. glass, Teflon, quartz, ceramic); reflecting/opaque materials (i.e. materials that do not allow microwaves to penetrate through them and react by reflecting microwaves (e.g. metals and other conductors); and receptors/dielectrics (i.e. good absorbers of microwaves, depending on their dielectric properties (e.g. activated carbon, water, electrolytes) (Larhed et al, 2002; Kappe, 2004). Generally, materials with $\tan \delta>0.5$ are referred to as good microwave absorbers, while those with $\tan \delta$ between 0.1 and 0.5 and those $<0.1$ are considered to be medium and low-microwave absorbers, respectively (Yin, 2012). However, a low $\tan \delta$ material can be blended with materials with a high $\tan \delta$ to improve its overall microwave absorptive capacity, as suggested in previous studies (Menendez et al, 2002; Sobhy and Chaouki, 2010).

\section{Technological feasibility of microwave heating for HFS processing}

\subsection{Suitability of microwave heating for processing HFS}

The theory behind the adoption of microwave heating for processing HFS is based on the concept that water, which constitutes up to 97 per cent w/w in HFS, efficiently couples with microwaves and this electromagnetic interaction causes dielectric heating. In other words, the electromagnetic copulation of water and other molecular dipolar organics in HFS with incident microwaves triggers dielectric heating that occurs at the molecular level. This can achieve both pathogenic deactivation and value recovery from HFS at optimal process conditions - such as microwave power, temperature and residence time of processing. Two main dielectric heating mechanisms explain this feasibility: thermal effects due to dipolar polarization/rotation and athermal effects triggered by ionic conduction/migration as shown in Fig 4 (Kappe, 2004; Yin, 2012). 


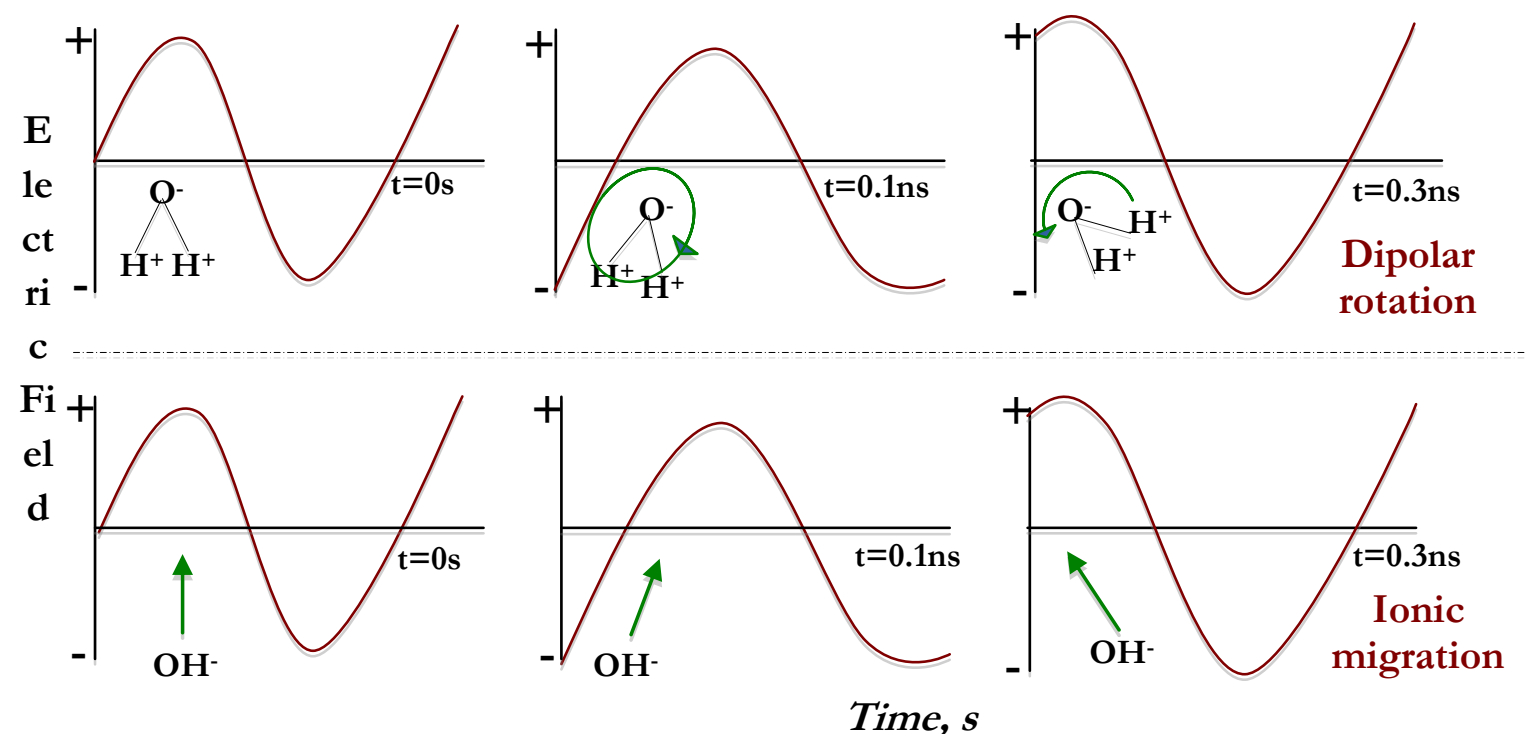

Fig. 4. Microwave dielectric heating mechanisms (Source: Yin, 2012)

Dipolar polarization is the primary heat-induction mechanism of microwave dielectric heating, which results from the direct coupling of molecular dipoles with electromagnetic microwaves. Dipolar materials such as water are highly sensitive to electric fields, as their local charges tend to move in response to an applied electric field. Dipolar polarization results from the interaction of incident microwave irradiation with molecular dipoles, causing the dipoles to respond by rotating in order to realign in the direction of the applied electromagnetic field. As the dipole reorientates to align itself with the field, the field is already changing, creating a phase difference between the orientation of the field and the dipole. This phase difference causes energy to be lost from the dipoles through random collisions/frictions at a frequency of $2.45 \mathrm{GHz}$ (i.e. occurring at 2.45 billion times per second), causing dielectric heating. In other words, dipole polarization lags behind an applied electric field due to the internal forces and/or bond resistance of realigning dipolar molecules, and this lag results in molecular friction or dielectric loss - characterized by energy loss dissipated in the form of heat (Bradshaw et al, 1998; Clark et al, 2000). Athermal effects, i.e. those not associated with temperature increase, have been attributed to the net effect of the continuous realignment of polarized dipoles to the electric field, and ionic migration - which occurs when an applied electrical field causes dissolved ions of positive and negative charges of heated dipolar materials to move towards oppositely charged regions of the field. This results in net collisions of dipoles and possible weakening of the hydrogen bonds within water molecules of heated material (Kappe, 2004; Venkatesh and Raghavan, 2004). 


\subsubsection{Odour eradication through thermal solubilization}

Microwave heating is capable of eradicating foul odour associated with HFS through thermolytic solubilization. Thermal hydrolysis during microwave heating can solubilize organic components of HFS, including those associated with foul odour, trapping them in the aqueous phase. As described in Section 2.0, the primary organics of HFS are carbohydrates, proteins and lipids. During microwave heating, these macromolecular compounds are hydrolyzed into shorter-chain intermediate monomers: carbohydrates into reducing sugars; proteins into saturated and unsaturated acids such as amino-acids, ammonia and carbon dioxide; while lipids are broken down into short-chain fatty acids such as palmitic acids and oleic acids (Lian-hai et al, 2006; Wilson and Novak, 2009). Studies have demonstrated this thermolytic solubilization capacity of microwave heating. Ahn et al, (2009) applied microwave heating at 700W for 15 minutes on sewage sludge and observed increases in concentrations of soluble carbohydrates from 0.07 to $0.9 \mathrm{~g} / \mathrm{L}$, protein from $0.15 \mathrm{~g} / \mathrm{L}$ to $0.9 \mathrm{~g} / \mathrm{L}$, and lipids from 0.07 to $0.85 \mathrm{~g} / \mathrm{L}$. Another study reported 297 per cent and 654 per cent increases in protein and carbohydrate concentrations after treating sewage sludge at 900W for 140 seconds ( $Y u$ et al, 2010). Under favourable conditions during microwave heating, especially those associated with high temperature $\left(>180^{\circ} \mathrm{C}\right)$, caramelization and/or the Maillard reaction may occur, and these reactions can affect the odour and colour of treated HFS. 'Caramelization' is a non-enzymatic browning effect observed on short-chain polysaccharide sugars processed at elevated temperatures (Labuza and Baisier, 1992), while Maillard reactions are associated with reducing sugar's reaction with amino acids known to generate dark brown-coloured complex compounds with characteristic smells (Penaud et al, 2000a; Dwyer et al, 2008). These were observed in a study where sewage sludge and HFS treated by microwave heating at $180^{\circ} \mathrm{C}$ and $200^{\circ} \mathrm{C}$ for 30 minutes generated a coal-like solid with a characteristic coffee-like and almond-like smell respectively (Afolabi et al, 2015).

Solubilizations of sulphur-containing compounds in HFS during microwave heating may also play a role in the reduction of odour (He et al, 2009). A study reported concentrations of dimethyl sulphide (8.1 ppm [v]) and methyl mercaptane (14.2 ppm [v]) in dewatered sewage sludge treated at $200^{\circ} \mathrm{C}$ falling to $11 \mathrm{ppb}(\mathrm{v}$ ) and $3 \mathrm{ppb}(\mathrm{v}$ ) in treated samples respectively (Namioka et al, 2011). In essence, reactive hydrolysis during microwave heating which renders sulphur-containing compounds non-volatile and dissolved into the liquid phase, coupled with a characteristic smell due to the thermal hydrolysis of carbohydrates and protein compounds and 
subsequent intermediate reactions such as caramelization and/or the Maillard reaction, are likely mechanisms that can ensure odour eradication of HFS using microwave heating. Transformation of the foul odour associated with HFS could improve public acceptance of the microwave heating method.

\subsubsection{Complete pathogenic deactivation}

Microwave irradiation appears to be a viable option for generating environmentally safe materials that will satisfy existing WHO recommendations and other statutory regulations on pathogen deactivations. Disinfection studies on sewage sludge (as the closest alternative to real human faecal sludge in terms of pathogenic loads) at temperatures $70^{\circ} \mathrm{C} \geq \mathrm{T} \leq 100^{\circ} \mathrm{C}$ and residence times ( $\leq 30$ minutes) under microwave irradiation, have demonstrated efficacy, i.e. such treatment can effectively kill bacterial pathogens (notably E. coli and helminthic eggs) (Khalil and Villota, 1988; Hong et al, 2004; Martin et al, 2005; Pino-Jelcic et al, 2006). Furthermore, hightemperature treatments can deactivate xenobiotic and endocrine-disrupting compounds in biowastes (Wilson and Novak, 2009), producing end products that are free of biologically active organisms and bioactive exogenous compounds (Peterson et al, 2008). Microwave exposure for 1 minute at $65^{\circ} \mathrm{C} 1.34 \mathrm{~W} \mathrm{~h} / \mathrm{g}$ TS resulted in a sludge of coliform densities less than $1,000 \mathrm{MPN} / \mathrm{g}$ total dried solids (Hong et al, 2006). Martin et al, (2005) also reported a similar observation at $85^{\circ} \mathrm{C}$, where sewage sludge irradiated at $670 \mathrm{~W}$ for 1 and 3 minutes resulted in complete destruction of coliforms to 33 and 2 total coliforms per $100 \mathrm{ml}$ respectively. At temperatures greater than $70^{\circ} \mathrm{C}$, more studies have reported no microorganism activity, i.e. no detection of coliforms or E. coli in pre-treated sludge (Hong et al, 2004; Martin et al, 2005; Eskicioglu et al, 2009; Park et al, 2010).

Both the thermal and athermal effects of microwave heating at these temperature ranges play a significant role in pathogenic deactivation. The extents to which both effects contribute to pathogen kill are still relatively unknown. Selective heating, electroporation, cell membrane rupture and magnetic field coupling have all been reported as mechanisms behind the capacity of microwave heating to kill pathogens and enzymes (Kozempel et al, 1998). The selective heating and magnetic field coupling mechanisms suggest that the cell membranes of microbes are composed permeable lipids, which have a strong affinity for microwave absorption. Thus incident microwaves selectively energize such polar substances, causing irreversible damage to the cell membranes through DNA disruption. This subsequently leads to rupturing of the cell walls and membranes, and release of intracellular materials - leading to eventual denaturation 
and death of the microbial cells (Belyaev et al, 1993; Kozempel et al, 1998). However, the electroporation and cell membrane rupture theories both seem to argue that electrical potential or voltage applied across the cell membrane causes a rupture or generation of pores, which subsequently results in leakage and release of intracellular materials (Kozempel et al, 1998). All the mechanisms points to the fact that microwave heating can attack coliform bacterial/microbial cell membranes, rupturing them and leading to their death. These theories have also been supported microscopically as SEM micrographs of raw and microwave irradiated sludgy material for 7 minutes (mins) at $2.45 \mathrm{Ghz}$ and $700 \mathrm{~W}$ showed that - while raw sludge was highly porous and contained filamentous bacteria - those obtained from treated sludge showed structural rupture and disintegrated microbial cells (Ahn et al, 2009). Zhou et al, (2010) have also used SEM micrographs to confirm the disintegration of Gram-negative bacteria cell walls after microwave irradiation. Regardless of the mechanism(s) involved, it is evident that microwave heating can be highly effective and efficient in ensuring the destruction of pathogenic loads associated with HFS.

\subsubsection{Enhanced dewaterability}

Microwave heating can significantly improve the dewaterability of sludgy material such as HFS. Dewaterability essentially reduces sludge volume and is crucial for waste treatment technologies. About 40 per cent improvement in dewaterability was reported as a result of microwave heating of anaerobically digested sludge at $96^{\circ} \mathrm{C}$ (Eskicioglu et al, 2007b). Increasing the temperature to $175^{\circ} \mathrm{C}$ resulted in a 75 per cent improvement in dewaterability (Eskicioglu et al, 2008a). Similarly, significant reduction in capillary suction time (CST) - a measure of dewaterability - of up to 600 seconds has been reported from microwave-irradiated sludge treated at $175^{\circ} \mathrm{C}$ at $900 \mathrm{~W}$ for a minute residence time (Toreci et al, 2009; Yu et al, 2009). To achieve sludge dewaterability, high microwave power (up to $900 \mathrm{~W}$ ), short residence times (less than 2mins) and temperature ranges over $120^{\circ} \mathrm{C}$ were recommended in another study (Yu et al, 2009).

Improved sludge dewaterability due to microwave heating has been attributed to both the thermal and athermal effects of microwave heating (Wojciechowska, 2005; Eskicioglu et al, 2007c, Toreci et al, 2009). Thermal effects result from direct coupling of electromagnetic energy with water molecules, which raise the temperature of sludgy materials, decrease their viscosity and enhance their filterability. In addition, microwaves can selectively energize chemically bound water in sludge to facilitate its chemical dissociation and release of bound water ( $\mathrm{Li}$ and Noike, 1992). In effect, the molecular heating effect of microwave irradiation facilitates the rapid 
disruption and disintegration of sludge flocs and bound water, and is responsible for improving dewaterability within a shorter (less than 2 mins in most cases) heating time (Wojciechowska, 2005; Yu et al, 2009). Athermal effects are attributed to the vibrational effects of microwaves on hydrogen bonds in the cell walls of sludgy materials through the alternation of the electric field of water (polar substance), causing overall weakening. This may also facilitate the breaking of chemically bound water in sludgy materials - i.e. the continuous aligning of polarized parts of materials' macromolecules and water molecules with the poles of the electromagnetic field at 2.45 billion times per second, for example, initiates vibrational effects that could lead to weakening and possible breakage of hydrogen bonds (Loupy, 2002; Eskicioglu et al, 2007c). Understanding of the contribution/extent to which both affect dewaterability is still evolving, but confirms microwave heating could enhance dewaterability of HFS.

\subsubsection{Heavy metals recovery}

Extraction and recovery of heavy metals can be both economical and environmentally attractive. Detoxification of processed HFS of heavy metals promotes environmental compatibility and ultimate prevention of soil and water pollution/contamination. Their recovery also makes them available for reuse.

Microwave treatments are generally used in the presence of suitable acids to digest and enhance the rapid dissolution of environmental samples for analysis/recovery, i.e. the microwave digestion process facilitates the extraction and recovery of heavy metals. A study recorded up to 104 per cent metals recovery efficiency for $\mathrm{Cd}$, chromium (Cr), $\mathrm{Cu}, \mathrm{Ni}, \mathrm{Pb}$ and $\mathrm{Zn}$ from sewage sludge treated at 900W for a minute contact time (Jamali et al, 2009). Another also reported that $\mathrm{Cu}$ ions were significantly leached from $179.4 \mathrm{mg} / 1$ to $6.5 \mathrm{mg} / 1$ in sewage sludge pre-treated at 600W for 3mins (Chen et al, 2005). Similar results were obtained with activated sewage sludge pre-treated at $70^{\circ} \mathrm{C}$ for 90 mins for the recovery of arsenic (As), molybdenum (Mb) (Danesh et al, 2008). Under favourable conditions, the thermal hydrolysis and subsequent solubilization reactions associated with microwave processing of HFS, for example, could facilitate the leaching of heavy metals, presenting them in ionic forms and effectively reducing the mobility of metal ions in the aqueous phase. Full heavy metal recovery transcends HFS microwave processing and may require additional processes, as reported in many studies (Perez-Cid et al, 1999; Perez-Cid et al, 2001; Kuo et al, 2005; Hsieh et al, 2008; Jamali et al, 2009). However, microwaving HFS is potentially feasible for heavy metal digestion for extraction and recovery. 


\subsubsection{Nutrient recovery}

Macromolecular protein and other nitrogenous compounds are sources of $\mathrm{N}$ in HFS. Microwave treatment can break down and enhance the solubilization of the protein components and other nitrogenous materials of HFS, i.e. microwaving HFS can flush $\mathrm{N}$ content in raw HFS into the liquor phase (as ammonia liquor concentrate) - supporting the proposition that human faecal sludge may be used as liquid fertilizer. At temperatures greater than $160^{\circ} \mathrm{C}$, these compounds are hydrolyzed and decomposed to amino acids, organic-N and ammonium compounds. With increasing temperature $\left(\geq 180^{\circ} \mathrm{C}\right)$, deamination and hydrolysis of amino acids into short-chain volatile fatty acids, ammonia and carbon IV oxide occurs (Sun et al, 2013). Fourier transform infrared spectroscopy (FTIR) and elemental CHN studies of thermally pretreated sewage sludge have further buttressed $\mathrm{N}$ delpetion into the liquor phase. FTIR analyses of thermally processed sewage indicated loss of $\mathrm{N}$-bands seen in raw sewage into the liquor phase of processed sewage sludge (Grube et al, 2006; Smidt and Meissl, 2007), while CHN analysis suggests signifcant partitioning into the liquor phase of the original $\mathrm{N}$ percentage characterized in raw samples (Bagreev et al, 2001; Afolabi et al, 2015). Ammonia recovery may be seen as an apparent additional economic benefit from microwaving HFS. However, its direct use in agriculture requires further assessment as high concentrations of ammonia are environmentally damaging for rivers and watercourses, and use and dispersal of such concentrates require management and planning.

Ammonia recovered could also be combined with phosphates and could potentially be used to produce other solid plant fertilizers such as struvite (magnesium ammonium phosphates) for agricultural purposes. Phosphorus recovery is essential to achieving this. Generally, phosphorus tends to have an affinity for the solid phases. Only 10-15 per cent of P can be recovered from sewage sludge treated at $180^{\circ} \mathrm{C}-240^{\circ} \mathrm{C}$ for up to $90 \mathrm{mins}$ (Sun et al, 2013). In addition to temperature conditions $>170^{\circ} \mathrm{C}$, catalysts are required to ensure $\mathrm{P}$ solubilization and release as phosphates of calcium and iron into the liquor phase prior to subsequent crystallization/precipitation into fertilizers such as struvite. For example, a study used hydrogen peroxide as a catalyst with microwave irradiation at $171^{\circ} \mathrm{C}$ for $5 \mathrm{mins}$ and was able to recover up to 84 per cent of $\mathrm{P}$ from sewage sludge (Liao et al, 2005). Similar results were obtained in another study where acids hydrolysis in the presence of hydrogen peroxide was used to recover 61 per cent of total $\mathrm{P}$ and 36 per cent of total Kjeldahl nitrogen (TKN) at $120^{\circ} \mathrm{C}$ for 5 mins (Wong et al, 2006). Although, microwaving HFS provides an opportunity for $\mathrm{P}$ recovery, 
additional downstream processing maybe required for higher recovery rates of phosphates suitable for agricultural use.

Comparable to $\mathrm{N}$ content, microwaving HFS at temperatures greater than $180^{\circ} \mathrm{C}$ can also favour the solubilization of $\mathrm{K}$ into the liquid phase. Up to 70 per cent $\mathrm{K}$ was recovered in liquid products from sewage sludge hydrothermally treated between $180^{\circ} \mathrm{C}$ and $240^{\circ} \mathrm{C}$; this reported a preferential partitioning of $\mathrm{N}$ and $\mathrm{K}$ into the liquor phase, in contrast with $\mathrm{P}$ which has a high affinity for the solid phase (Liao et al, 2005; Sun et al, 2013). Nonetheless, the retention of P in solid product chars may be seen as an advantage, for $\mathrm{P}$ is a nutrient for crop growth. If used as solid fuel, phosphorus can be recovered in the ash content of combusted chars (Escala et al, 2012). Consistent with industrial practices, the prices of $1 \mathrm{~kg} \mathrm{~N}$ (as $\mathrm{TN}$ ), $1 \mathrm{~kg} \mathrm{P}$ (as $\mathrm{K}_{2} \mathrm{O}$ ) and $1 \mathrm{~kg}$ $\mathrm{K}$ (as $\mathrm{KCl}$ ) in commercial fertilizers has been up to US $\$ 13.22$, US $\$ 11.27$ and US $\$ 6.63$ respectively over the last decade. ${ }^{2}$ Hence the recovery of nutrients from HFS represents a feasible financial benefit to the whole faecal sludge management chain.

\subsubsection{Carbon and energy recovery}

Carbon recovery is essential for diverse uses including energy, sequestration and fixation into agricultural soil. Under favourable conditions such as those associated with the carbonization process - i.e. heating at temperatures $160^{\circ} \mathrm{C}-250^{\circ} \mathrm{C}$ in the absence of oxygen under autogenous pressure (Peterson et al, 2008; Libra et al, 2011) - microwave heating can be used to process HFS to recover energy-densified solids called chars (Wahi et al, 2006; Tian et al, 2013; Afolabi et al, 2015). These chars are characterized by a significantly higher heating value of up to $25 \mathrm{MJ} / \mathrm{kg}$ (as against $19 \mathrm{MJ} / \mathrm{kg}$ recorded in raw HFS) (Afolabi et al, 2015); and are coal-like in appearance and highly porous (which enhances air distribution during combustion), making them suitable candidates for fuels. The relatively higher heating value (HHV) and energy yield from chars unlocks opportunities for co-combustion with low-rank coals (with similar ranges of HHV) (Speight, 2005) for energy generation, although thermal compatibility requires further and careful assessment (Parshetti et al, 2013). Even at higher temperatures, microwave pyrolysis of sewage sludge has yielded other biofuels such as bio-oil and gaseous hydrocarbon (Menendez et al, 2002; Tian et al, 2013). Wahi et al, (2006) in their study, microwaved sewage sludge at $650^{\circ} \mathrm{C}$ and recovered 28 per cent chars, 6 per cent bio-oil and 68 per cent gaseous hydrocarbon, with HHV of the bio-oil and chars being $28.9 \mathrm{MJ} / \mathrm{kg}$ and $12.4 \mathrm{MJ} / \mathrm{kg}$ respectively. These are similar results to

\footnotetext{
2 Values were obtained from studying price variations for commodity fertilizers over ten years at: http://www.indexmundi.com/commodites/
} 
those of many other studies that have demonstrated the efficacy of using the microwave process to generate fuel in the forms of chars, bio-oil and gaseous hydrocarbons from sewage sludge at temperatures ranging between $200^{\circ} \mathrm{C}$ and $1000^{\circ} \mathrm{C}$ (Dominguez et al 2003, 2005, 2006; and 2008).

Chemical oxygen demand (COD) indicates the fractions of carbon transferred into the liquid phase from hydrolysis and solubilization of organic and inorganic components during thermal treatment, such as those associated with microwave irradiation. Apart from disposal processes, soluble COD is a helpful measure for assessing liquor use as a substrate for anaerobic digestion (AD) to recover biogas fuel (Bougrier et al, 2008; Tyagi and Lo, 2011). Microwave has been studied and used extensively to increase the concentration of soluble COD in sludgy materials especially for AD (Zheng et al, 2009; Eskiciolgu et al, 2006; Eskiciolgu et al, 2007a; Yeneneh et al, 2015). COD obtained for microwave analyses of HFS liquors ranges between $21 \mathrm{~g} / \mathrm{L}$ to $26 \mathrm{~g} / \mathrm{L}$ (Afolabi et al, 2015) and is comparable with those recovered from sewage sludge studies (Dwyer et al, 2008; Wilson and Novak, 2009; Eskicioglu et al, 2009), indicating utility for anaerobic digestion. In general, temperatures in the range $160^{\circ} \mathrm{C}$ to $180^{\circ} \mathrm{C}$ are considered to be optimal for generating AD feedstock from biowastes, based on COD concentration ( $\mathrm{Li}$ and Nioke, 1992; Wilson and Novak, 2009). Higher temperatures were reported to decrease the biodegradability of sludge (Stuckey et al, 1978; Bougrier et al, 2008).

Future research in this area could involve the standardization of optimum temperature range, microwave power and residence time required to achieve both HFS treatment and value recovery. This will be crucial for the design of microwave-based sanitation facilities.

\subsection{Comparing microwave irradiation with conventional heating for processing HFS}

Microwave heating potentially represents a better heating approach for processing HFS over conventional conduction heating methods. Specifically, microwave heating causes selective and rapid volumetric heating and faster reaction rates, which make it superior to conventional heating (Clark et al, 2000; Dominguez et al, 2006; Yin, 2012). The main differences between microwave and conventional heating processes are summarized in Table 2. The overarching implications of these can be seen in time and energy savings and associated costs of processing.

The conventional heating process is characterized by an external supply of heat transferred by thermal gradients via conduction, convection and radiation to heated material, i.e. the heat supplied penetrates from the surface towards the core of the heated material, causing the outer 
region of heated components (i.e. reactor vessels and material surfaces) to be hotter than their inner regions. This is inefficient when compared with what occurs during microwave heating. When microwaves heat materials, selective heating of dipoles occurs throughout the heated material (as microwaves can penetrate and deposit energy throughout the volume of the material), causing a uniform and rapid volumetric heating effect. As a result, the inner regions of the heated material become hotter and this reduces the chance of surface drying/degradation, which is commonly associated with conduction heating (Remya and Lin, 2011). In addition, since most microwave handling components are good insulators, e.g. quartz or glass, this causes a reverse thermal gradient - i.e. a higher temperature at the core and lower temperature at the surface (Clark et al, 2000). Also, in conventional processes, heating is slower because (source energy such as electric) energy is first converted into heat energy, before being transferred to the sample material from the conducting surface. In microwave heating, microwave energy is delivered directly to the heated material through molecular interactions with the electromagnetic field. Heat is induced within the core of the material through the direct conversion (rather than transfer of heat) of microwaves into calorific heat, thereby turning the material into a heat source. As a result, microwave heating provides faster and more energy-efficient heating. This feature has been linked with the accelerated reaction rates microwave heating offers, because turning the heated material to a heat source can lead to an alteration of reaction kinetics with energy-saving implications (Appleton et al, 2005; Sobhy and Chaouki, 2010). Conventional processes also tend to require the construction of processing equipment in situ. Using microwave heating can overcome this problem due to the relatively lower footprint of the technology. Reactor vessels used for conventional processes are usually thick-walled metallic conductors, which must withstand pressurized conditions and sometimes the corroding environment associated with high-temperature processes. This may have cost implications, especially when scaling the process. However, with microwave heating this can be avoided, as metals are poor microwave conductors; hence cheap and readily available insulators such as ceramic and other refractory materials can be used to design treatment/processing reactor vessels. 
Table 2 Microwave versus conventional heating

\begin{tabular}{|c|c|c|}
\hline Parameters & Microwave heating & Conventional heating \\
\hline Energy & $\begin{array}{l}\text { Conversion of energy from electromagnetic to } \\
\text { heating, i.e. energy transfer }\end{array}$ & $\begin{array}{l}\text { Transfer of heat associated with } \\
\text { thermal gradients, i.e. heat } \\
\text { transfer }\end{array}$ \\
\hline Heating & $\begin{array}{l}\text { 1. In-core volumetric and uniform heating, } \\
\text { simultaneously heating materials due to } \\
\text { energetic coupling at molecular level } \\
\text { 2. Non-contact heating }\end{array}$ & $\begin{array}{l}\text { 1. Superficial heating via } \\
\text { conduction / convection } \\
\text { 2. Need for contact between } \\
\text { heating source and heated } \\
\text { material }\end{array}$ \\
\hline Rate & $\begin{array}{l}\text { Rapid and efficient rate of heating due to } \\
\text { molecular interaction at a very high frequency; } \\
\text { hence desired peak temperature can be reached } \\
\text { quicker }\end{array}$ & $\begin{array}{l}\text { Slow, inefficient, limited by } \\
\text { material thermal conductivity }\end{array}$ \\
\hline Selectivity & $\begin{array}{l}\text { Highly selective for polar substances, but poor } \\
\text { for non-polar materials, and hence can trigger } \\
\text { new products }\end{array}$ & Non-selective \\
\hline Hotspots & $\begin{array}{l}\text { Localized hotspots due to in-homogeneities of } \\
\text { microwave electric field concentration or due to } \\
\text { dielectric properties within material; this causes } \\
\text { arcing, i.e. temperature within material to be } \\
\text { higher than bulk temperature of material }\end{array}$ & No hotspots \\
\hline $\begin{array}{l}\text { Dependence } \\
\text { on nature of } \\
\text { heated } \\
\text { materials }\end{array}$ & $\begin{array}{l}\text { Highly dependent on dielectric properties of the } \\
\text { material }\end{array}$ & Less dependant \\
\hline $\begin{array}{l}\text { Heating } \\
\text { control } \\
\text { features }\end{array}$ & $\begin{array}{l}\text { Enhanced control and process monitoring } \\
\text { features; precise on/off power and temperature } \\
\text { controls; energy input can be stopped abruptly }\end{array}$ & Poor controllable nature \\
\hline Cooling rate & $\begin{array}{l}\text { Faster cooling rates due to enhanced cooling } \\
\text { units }\end{array}$ & Longer cooling rates \\
\hline Particle size & Not sensitive to particle size & $\begin{array}{l}\text { Highly sensitive to particle size in } \\
\text { terms of enhancing heating rate }\end{array}$ \\
\hline
\end{tabular}

\section{Key technological and design parameters considerations for microwave technology crucial for scaling microwave for sanitation purposes}

Most of the successes and feasibility studies conducted in the use of microwave irradiation for processing biomass/biowastes are largely laboratory based, involving relatively small quantities of samples. As with any technology, there are parameters that must be duly considered for optimization and design at various stages of scaling. These parameters are considered below. 


\subsection{Dielectric properties of HFS components}

Microwave heating induces physicochemical and structural transformation as materials are been processed, and these transformations affect dielectric properties - and by extension the ability of microwaves to generate heat varies during the process. It is necessary to determine the dielectric properties (dielectric capacity and loss) of human faeces or urine over microwave frequency ranges and at different temperature regimes, particularly those associated with HFS treatment and product recovery to optimize the microwave heating efficiency. Determination of the dielectric properties depends on many factors such as temperature changes, microwave frequency, moisture content, the chemical composition of material, density of material and physical characteristics of material (homogeneity and particle size distribution) (Thostenson and Chou, 1999), and these may present a significant developmental challenge for highly heterogonous and variable HFS. Furthermore, key parameters such as power absorption (i.e. the amount of transmitted microwave power absorbed per unit volume by heated materials from the electromagnetic microwave distribution) and heating rate (i.e. measures of the amount of power absorbed that is converted to heat within the material) - which are crucial for enhancing microwave-heating efficiency - are largely dependent on the dielectric properties of materials irradiated, as shown in Equations 2 and 3 (Venkatesh and Raghavan, 2004; Kappe, 2004).

$$
P_{v}=2 \pi f \varepsilon_{0} \varepsilon^{\prime} \operatorname{Tan}(\delta)|E|^{2} \quad \text { Equation } 2
$$

Where $P_{v}$ : Power absorbed per unit volume of material, $\mathrm{W} / \mathrm{m}^{3}$

$f:$ Frequency of microwave, $\mathrm{Hz}$

$\varepsilon_{0}$ : Permittivity of free space $=8.85 \times 10^{-12} \mathrm{~F} / \mathrm{m}$

$\varepsilon^{\prime}:$ Dielectric constant

$\operatorname{Tan}(\delta)$ : Tangent loss, where $(\delta)$ is the loss angle

$E$ : Electric field, $\mathrm{V} / \mathrm{m}$

$$
\frac{\Delta T}{\Delta t}=\frac{P_{v}}{\rho C_{p}} \quad \text { Equation } 3
$$

Where $\Delta \mathrm{T}$ : Change in temperature, $\mathrm{K}$

$\Delta \mathrm{t}$ : Residence time involved, Seconds

$\rho$ : Density of the material, $\mathrm{kg} / \mathrm{m}^{3}$

$\mathrm{C}_{\mathrm{p}}$ : Heat capacity of the material, $\mathrm{J} / \mathrm{K}$

$\mathrm{P}_{\mathrm{v}}$ : Power absorption of material, $\mathrm{W} / \mathrm{m}^{3}$ 


\section{2}

\section{Penetration depth}

Penetration depth, $\mathrm{D}_{\mathrm{p}}$, is the distance at which transmitted microwave power drops to $\exp ^{-0.368}$ (equivalent to 36.8 per cent) from its original value at the surface of the heated material. Beyond this depth, volumetric heating due to microwave energy is insignificant. This parameter is particularly important for determining the uniformity of heating in a material. Penetration depth is estimated as:

$$
\mathrm{D}_{\mathrm{p}}=\frac{3 \lambda_{0}}{8.686 \pi \tan \delta\left(\sqrt{\frac{\varepsilon^{\prime}}{\varepsilon_{0}}}\right)} \quad \text { Equation } 4
$$

and is related to frequency of microwave irradiation as:

$$
\mathrm{D}_{\mathrm{p}}=\frac{\mathrm{c} \varepsilon_{0}}{2 \pi \mathrm{f} \varepsilon^{\prime \prime}} \quad \text { Equation } 5
$$

Where $\lambda_{0}$ and c: Incident wavelength of microwave (m) and speed of light (m/s)

It follows that penetration depth is dependent on the frequency of microwaves and the dielectric properties of an irradiated material Higher frequencies and larger dielectric properties will produce low penetration depth and cause on-surface heating of the material, while lower frequencies and smaller dielectric properties of a material will promote volumetric heating (Clark et al, 2000; Tyagi and Lo, 2013a). For instance, penetration depths for $915 \mathrm{MHz}$ microwaves are about three times larger than for $2.45 \mathrm{GHz}$ microwaves. This is the main reason for the wider application of this frequency in large-scale industrial systems.

In addition, penetration depth is inversely proportional to absorption of microwaves in a material. This means that the size of treated material, for instance the size of the container holding waste, should be about the same as the penetration depth. It follows that if the penetration depth of incident microwaves is less than the thickness of the sample, only the surface of the material will be irradiated and heated, while the rest will heated by conduction (Yin, 2012). In contrast, if the size of the sample is much smaller than the penetration depth, most of the microwaves will go through the sample without being absorbed.

Table 3 further relates the temperature and moisture content dependence of penetration depths. From Table 3, cold water absorbs microwaves about four times stronger than hot water. This means that colder parts will warm up faster, resulting in a more uniform heating. Table 3 also suggests that increasing moisture content and temperature may increase penetration depth. More 
studies are needed on optimized penetration depth for both moisture content level and microwave temperature of treatment.

Table 3 Microwave energy penetration depth at 2.45GHz (extracted from Decareau 1985; Puschner Microwave Power Systems, 2016)

\begin{tabular}{cc}
\hline Materials & Penetration depth $\mathbf{( c m )}$ \\
\hline Material with high moisture $(\mathbf{> 5 0} \%)$ & 3.1 \\
Material with intermediate moisture & 4.4 \\
Material with low moisture $(\leq \mathbf{3 0} \%)$ & 8.2 \\
Water at $\mathbf{2 5}{ }^{\circ} \mathbf{C}$ & 1.4 \\
Water at $\mathbf{9 5}{ }^{\circ} \mathbf{C}$ & 5.7 \\
Ice at $\mathbf{- 1 2} \mathbf{C}^{\circ}$ & 1,100 \\
Sewage sludge $\mathbf{( 9 6 \%}$ moisture) & $0.2^{*}$ \\
HFS $\mathbf{( 9 5 \%}$ moisture) & $1.9^{*}$ \\
\hline
\end{tabular}

$*$ Unpublished experimental data determined at $15+/-2^{\circ} \mathrm{C}$

\subsection{Cold and hot spots, effective electromagnetic coupling and microwave power efficiency}

As microwave energy is transferred by the electromagnetic field, non-uniformity within the electromagnetic field may result in non-uniform heating (Thostenson and Chou, 1999; Remya and Lin, 2011). For example, microwave ovens use standing waves confined inside a metal resonant cavity. This means that microwave amplitude and power generation density are functions of position. Cavity locations where amplitudes of standing waves are near maximum will experience much larger heat generation density as compared to locations where microwave amplitude is near zero. This effect causes hot and cold spots during microwave irradiation.

The existence of hot and cold spots may affect the design of the toilet waste treatment system, if the cavity is not properly designed to alternate and expose material to uniform irradiation. Batch systems or semi-continuous systems, where the waste moves in discrete batches, may also encourage hot/cold spots generation. Waste in cold spots may experience incomplete pathogen deactivation, especially if mixing of waste is not sufficient to average out microwave exposure. A common approach to eliminate hot and cold spots is to use a turntable, as obtained in kitchen microwaves. The turntable moves irradiated materials between hot and cold spots and provides an averaged and more uniform heating. An alternative approach, although not frequently used, is to employ a rotating metal reflector or stirrer installed inside of the microwave cavity. The reflector/stirrer effectively shifts the location of hot/cold spots, allowing for uniform heating. 
One of the challenges of microwave heating is to ensure efficient absorption, i.e. coupling between microwaves and the treated material. Understanding the generation, propagation and interaction of microwaves with materials is critical to ensuring effective coupling. Reflection of microwaves at material interfaces, too short or too long microwave penetration depth, and/or overall poor design of the microwave cavity may result in poor coupling. This requires careful assessment, to prevent significant impact on the advantageous kinetics of microwave HFS processing. Even with perfect coupling, a microwave magnetron will convert only about 50 per cent (for $2.45 \mathrm{GHz}$ ) and 85 per cent (for $915 \mathrm{Mhz}$ ) of the electrical energy into microwaves (Engelhart, 1992; Haque, 1999), while the remainder is dissipated as heat inside of the magnetron source. This conversion efficiency is apparently dependent of microwave frequency and should be considered when designing off-grid microwave-based sanitation systems for HFS processing.

\subsection{Temperature and pressure measurements}

The challenge of precise temperature measurement within the core of the heated material during the microwave process has also been highlighted in a few reports (Tian et al, 2013; HoseinzadehHesas et al, 2013). Most measurements are conducted externally via infrared pyrometers. Effective temperature monitoring within the core of heated HFS and autogenous pressure buildup from the exothermic reactions associated with high temperature treatment of HFS, is crucial for modelling and control designs. Other important factors - such as cavity design, choice of materials to design reactors for processing HFS, and process conditions that will achieve both treatment and value recovery - also require careful assessment during design and scaling of microwave technology for HFS processing.

\section{Conclusion}

This review discussed the characteristic value compositions of HFS as a significant nutrient-based resource and explored microwave heating as viable method that can both treat and recover value from HFS. The high-moisture content (up to 97 per cent) that characterizes HFS makes it fit the dielectric heating spectrum, and may trigger very rapid and volumetric heating, promote novel reaction pathways and enhance reaction rates. Enhanced reaction rates present an opportunity to develop higher throughputs. Microwaves can potentially eradicate foul odours and kill pathogens efficiently, thereby making products safe to handle. This may further boost public acceptability of the technology. 
The highly selective nature of microwave heating targeting dipoles can trigger novel reactions that can lead to molecular and structural changes in processed HFS, and thus provide for the generation of new products. Ammonia liquor concentrate, and biofuel such as chars, bio-oil and biogas products for diverse applications in agriculture and energy generation, are examples of the valuable products that are potentially recoverable from microwaving HFS. Successful dewatering, plant nutrients and fuels recovery from microwaving HFS could improve the financial incentives for waste management in both developed and developing countries, if the contingent sustainability value of the process is assessed.

However, crucial technological factors - such as the dielectric properties of HFS components (especially at high temperatures, which may be required to achieve both treatment and value recovery) and the physics of the microwave/HFS interactions during heating - are necessary investigations to optimize the efficiency of the microwave heating process. As the microwave processing equipment will determine the electromagnetic field, the design of microwave equipment (especially the cavity design) is also particularly important. Hence, more work on system designs, development and performance improvement of the microwave technology, outside laboratory applications, is necessary to feed into the integration of the technology for sanitation purposes.

\section{Acknowledgement}

The authors would like to thank The Bill \& Melinda Gates Foundation, Seattle WA for its funding to Loughborough University, UK for the 'Reinvent the Toilet Project' which inspired this work. The views expressed in this paper are the authors' own. We also thank the anonymous reviewers for their very helpful and insightful comments, which have helped improve this article. 


\section{References}

Afolabi, O.O.D., Sohail, M., Thomas, C.P.L., 2015. Microwave Hydrothermal Carbonization of Human Biowastes, Waste and Biomass Valorization, 6(2), 147-157.

Ahn, J.H., Shin, S.G., Hwang, G. 2009. Effects of microwave irradiation on the disintegration and acidogenesis of municipal secondary sludge. Chemical Engineering Journal, 153, 145-150.

Appleton, T.J., Colder, R.I., Kingman, S.W., Lowndes, I.S., Read, A.G, 2005. Microwave technology for energy-efficient processing of waste. Applied Energy, 81, 85-113.

Bagreev, A., Bandosz, T.J., Locke, D.C., 2001. Pore structure and surface chemistry of adsorbents obtained by pyrolysis of sewage sludge-derived fertilizer. Carbon, 39 (13), 1971-1979.

Bai, F., Wang, X., 2011. Study on dynamics model of biodegradation of organic matter in aerobic mesophilic composting reactor for sanitary disposal of human feces. In International Conference on Environmental, Biomedical and Biotechnology, 3, 19-21 August, Shanghai. Singapore: IACSIT Press, $11-16$.

Barjenbruch, M., Kopplow, O., 2003. Enzymatic, mechanical and thermal pre-treatment of surplus sludge. Advances in Environmental Research, 7, 715 - 720.

Belyaev, I.Y., Alipov, Y.D., Polunin, V.A., Shcheglov, V.S. 1993. Evidence for dependence of resonant frequency of millimetre wave interaction with E.Coli $\mathrm{K}-12$ cells on haploid genome length. Electro and Magnetobiology, 12, 39-49.

Bender, D.A., Bender, A.E., 1997. Nutrition; a reference handbook (1st ed.). New York, NY: Oxford University Press.

Borawski, K.M., Sur, R.L., Miller, O.F., Pak, C.Y.C., Preminger, G.M., Kolon, T.F., 2008. Urinary reference values for stone risk factors in children. Journal of Urology, 179(1), 290-294. Bougrier, C., Delgenes, J.P., Carrere, H., 2008. Effects of thermal treatment of five different waste-activated sludge samples solubilisation, physical properties and anaerobic digestion. Chemical Engineering Journal, 139(2), 236-244.

Bradshaw, S.M., van Wyk, E.J., de Swardt, J.B, 1998. Microwave heating principles and the applications to regeneration of granular activated carbon. The Journal of The South African Institute of Mining and Metallurgy. 98(4), 201-210. 
Cain, W.S., Cometto-Muniz, J.E., 2004. Identifying and controlling odour in the municipal wastewater, environment: Health effects of biosoilds odours: A literature review and analysis. London: IWA Publishing. Calloway, D.H., Margen, S., 1971. Variation in endogenous nitrogen excretion and dietary nitrogen utilization as determinants of human protein requirement. The Journal of Nutrition, 101(2), 205-216.

Canfield, J., Goldner, B., Lutwack, R., 1963. Research on Applied Bioelectrochemistry; First quarterly progress report (NASA-CR-71834). Anaheim, CA: NASA.

CDC, 2011. Waterborne Illnesses. www.cdc.gov/nceh/vsp/training/videos/transcripts/water.pdf.

Chaggu, E.J., 2004. Sustainable environmental protection using modified pit-latrines. Unpublished PhD thesis. Wageningen, Holland: Wageningen Universiteit.

Chen, C.L., Lo, S.L., Kuan, W.H., Hsieh, C.H., 2005. Stabilization of Cu in acid-extracted industrial sludge using a microwave process. Journal of Hazardous Materials. B 123, 256-261.

Chen, H.L., Haack, V.S., Janecky, C.W., Vollendorf, N.W., Marlett, J.A., 1998. Mechanisms by which wheat bran and oat bran increase stool weight in humans. The American Journal of Clinical Nutrition, 68(3), 711-719.

Chen, Y., Cheng, J.J., Creamer, K.S., 2008. Inhibition of anaerobic digestion process: A review. Bioresource Technology, 99(10), 4044-4064.

Chrostowki, P., Foster, S., 2003. Odour Perception and Health Effects. In 76th Water Environment Federation Technical Exhibition and Conference (WEFTEC). Los Angeles, California.

Clark, D.E., Folz, D.C, West, J.K., 2000. Processing materials with microwave energy. Materials Science and Engineering, A287, 153-158.

Cofie, O.O., Agbottah, S., Strauss, M., Esseku, H., Montangero, A., Awuah, E., Kone, D., 2006. Solid-liquid separation of faecal sludge using drying beds in Ghana: Implications for nutrient recycling in urban agriculture. Water Research, 40, 75-82.

Cofie, O.O., Kranjac-Berisavljevic, G., Drechsel, P., 2005. The use of human waste for periurban agriculture in Northern Ghana. Renewable Agriculture and Food Systems, 20(02), 73-80.

Cordero, T., Marquez, F., Rodriguez-Mirasol, J., Rodriguez, J.J., 2001. Predicting heating values of lignocellulosics and carbonaceous materials from proximate analysis. Fuel, 80 (11), 1567-1571. 
Danesh, P., Hong, S.M., Moon, K.W., Park, J.K., 2008. Phosphorus and heavy metal extraction from wastewater treatment plants sludge using microwave for the generation of exceptional biosolids. Water Environment Research, 80, 784-795.

Decareau, R.V. 1985. Microwaves in the food processing industry. New York: Academic Press Inc.

Del Porto, D., and Steinfeld, C., 1999. The composting toilet system book. A practical guide to choosing, planning and maintaining composting toilet systems, an alternative to sewer and septic systems. The Concord, Massachusetts: Centre for Ecological Sanitation Prevention (CEPP).

Demirbas, M.F., Balat, M., Balat, H., 2011. Bio-waste to biofuels. Energy Conversion and Management, 52, 1815-1828.

Doğruel, S., and Özgen, A. S., 2016. Effect of ultrasonic and microwave disintegration on physico-chemical and biodegradation characteristics of waste-activated sludge. Environmental Technology, DOI: 10.1080/09593330.2016.1213771

Dominguez, A., Fernandez, Y., Fidalgi, B., Pis, J.J., Menendez, J.A., 2008. Bio-syngas production with low concentration of $\mathrm{CO}_{2}$ and $\mathrm{CH}_{4}$ from microwave-induced pyrolysis of wet and dried sewage sludge. Chemosphere, 70, 397-403.

Dominguez, A., Menendez, J.A., Inguanzo, M., Bernad, P.L., Pis, J.J., 2003. Gas

chromatographic-mass spectrometric study of the oil fractions produced by microwave-assisted pyrolysis of different sewage sludges. Journal of Chromatography, A 1012, 193-206.

Dominguez, A., Menendez, J.A., Inguanzo, M., Pis, J.J., 2005. Investigations into the characteristics of oils produced from microwave pyrolysis of sewage sludge. Fuel Processing Technology, 86, 1007-1020.

Dominguez, A., Menendez, J.A., Inguanzo, M., Pis, J.J., 2006. Production of bio-fuels by high temperature pyrolysis of sewage sludge using conventional and microwave heating. Bioresource Technology, 97, 1185-1193.

Drangert, J.O., 1998. Fighting the Urine Blindness to Provide More Sanitation Options. Water South Africa, 24 (2), April 1998.

Dwyer, J., Starrenburg, D., Tait, S., Barr, K., Batstone, D.J., Lant, P., 2008. Decreasing activated sludge thermal hydrolysis temperature reduces product colour, without decreasing degradability. Water Research, 42, 4699-4709. 
Eastwood, M.A., Brydon, W.G., Baird, J., Elton, R., Helliwell, S., Smith, J., Pritchard, J., 1984. Fecal weight and composition, serum lipids, and diet among subjects aged 18 to 80 years not seeking health care. The American Journal of Clinical Nutrition, 40(3), 628-634.

Eckhoff, P., Wood, L., 2011. Reinvent the toilet challenge: Concept and background. For the Bill and Melinda Gates Foundation. WA

Engelhart, W. G. for CEM Corporation American Environmental Lab, 1992. Microwave Power Calibration: Considerations in the Standardization of Sample Preparation Methods. RD063

Escala, M., Zumbuehl, T., Koller, C., Junge, R., Krebs, R., 2012. Hydrothermal carbonisation as an energy efficient alternative to established drying technologies for sewage sludge: A feasibility study on laboratory scale. Energy Fuels.

Eskicioglu, C., Droste, R. L., Kennedy, K. J. 2007a. Performance of anaerobic waste activated sludge digesters after microwave pretreatment. Water environment research, 79, 2265 - 2273.

Eskicioglu, C., Kennedy, K. J., Droste, R. L. 2006. Characterization of soluble organic matter of waste activated sludge before and after thermal pretreatment. Water research, 40, 3725 -3736.

Eskicioglu, C., Kennedy, K. J., Droste, R. L. 2009. Enhanced disinfection and methane production from sewage sludge by microwave irradiation. Desalination, 248, $279-285$.

Eskicioglu, C., Kennedy, K.J., Droste, R.L., 2007b. Enhancement of batch waste activated sudge digestion by microwave pretreatment. Water Environment Research, 79, 2304-2317.

Eskicioglu, C., Prorot, A., Marin, J., Droste, R. L., Kennedy, K. J., 2008b. Synergetic pretreatment of sewage sludge by microwave irradiation in presence of $\mathrm{H}_{2} \mathrm{O}_{2}$ for enhanced anaerobic digestion. Water research, 42, $4674-4682$.

Eskicioglu, C., Terzian, N., Kennedy, K.J., Droste, R.L., Hamoda, M., 2007c. Athermal microwave effects for enhancing digestibility of waste activated sludge. Water Research, 41, $2457-$ 266.

Eskiciolglu, C., Kennedy, K.J., Droste, R.L., 2008a. Initial examination of microwave pretreatment on primary, secondary and mixed sludges before and after anaerobic digestion. Water and Science Technology, 57, 311-317.

Etter, B., Tilley, E., Khadka R., Udert K.M., 2011. Low-cost struvite production using sourceseparated urine in Nepal. Water Research, 45(2), 852-862. 
Feachem, R.G., Bradley, D.J., Garelick, H., Mara, D.D., 1983. Sanitation and Disease. Health aspects of excreta and wastewater management. World Bank studies in water supply and sanitation. New York: John Wiley and Sons.

Feachem, R.G., Bradley, D.J., Mara, D.D., 1978. Health aspects of excreta and wastewater management $\left(1^{\text {st }}\right.$ ed). Washington, DC: World Bank.

Franceys, R., Pickford, J., Reed, R., 1992. A guide to development of on-site sanitation. Geneva: WHO. Friedl, A., Padouvas, E., Rotter, H., Varmuza, K., 2005. Prediction of heating values of biomass fuel from elemental composition. Analytica Chimica Acta, 544(1-2), 191-198.

Fry, L.J., Merrill, R., 1973. Methane digesters for fuel gas and fertilizer (1st ed.). Hatchville, MA: New Alchemy Institute.

Ganong, W.F., 1983. Review of Medical Physiology (11th Ed.) CA, USA: Lange Medical Publication. Grube, M., Lin, J.G., Lee, P.H., Kokorevicha, S., 2006. Evaluation of sewage sludge-based compost by FT-IR spectroscopy. Geoderma, 130, 324-333.

Guyton, A.C., Hall, J.E., 2000. Textbook of Medical Physiology (10th ed.). Philadelphia: W.B. Saunders Company.

Hansen, J.A., Tjell, J.C., 1979. Human Excretion of Heavy Metals and other Elements. Working document. Technical University of Denmark. The Laboratory for Technical Hygiene, now known as Environment and Resources.

Haque, K.E, 1999. Microwave energy for mineral treatment processes - a brief review. International Journal of Mineral Processing. 57(1), 1-24.

He, C., Li, X-Z., Sharma, V.K., Li, S-Y, 2009. Elimination of sludge odour by oxidizing sulphurcontaining compounds with ferrate (VI). Environmental Science and Technology, 43, 5890-5895.

Heaton, K.W., Lewis, S.J., 1997. Stool form scale as a useful guide to intestinal transit time. Scandinavian Journal of Gastroenterology, 32(9), 920.

Heinonen-Tanski, H., van Wijk-Sijbesma, C., 2005. Human excreta for plant production. Bioresource Technology, 96(4), 403-411.

Heinss, U., Larmie, S.A., Strass, M., 1998. Solids separation and pond systems for the treatment of faecal sludge in the Tropics. Lessons learnt and recommendations for preliminary design. SANDEC Report No 5/98. Dubendorf: EAWAG/SANDEC publications. 
Hemkend-reis, B., Henseler, M., Gudel, K., 2008. Faecal Sludge Management (FSM). SANDEC: Department of Water and Sanitation in Developing Countries Training Tool 1.0-Module 5. Dubendorf: EAWAG/SANDEC publications.

Hong, S.M., Park, J.K., Lee, Y.O., 2004. Mechanisms of microwave irradiation involved in the destruction of faecal coliforms from bio-solids. Water Research, 38(6), 1615-1625.

Hong, S.M., Park, J.K., Teeradej, N., Lee, Y.O., Cho, Y.K., Park, C.H., 2006. Pre-treatment of sludge with microwaves for pathogen destruction and improved anaerobic digestion performance. Water Environment Research, 78, 76-83.

Hoseinzadeh Hesas, R., Wan Daud, W-M.A., Sahu, J.N., Arami-Niya, A., 2013. The effects of microwave heating method on the production of activated carbon from agricultural waste: A review. Journal of Analytical and Applied Pyrolysis. http://dx.doi.org/10.1016/i.jaap.2012.12.019 Hsieh, C.H., Lo, S.L., Hu, C.Y., Shih, K., Kuan, W.H., Chen, C.L., 2008. Thermal detoxification of hazardous metal sludge by applied electromagnetic energy. Chemosphere, 71(9), 1693-700.

Hu, Y., Liu, C., Zhang, Y., Ren, N., Tang, Y., 2009. Microwave-assisted hydrothermal synthesis of Nano-zeolites with controllable size. Microporous and Mesoporous Materials, 119 (1-3), 306-314. Ifrah, S., Kaddouri, A., Gelin, P., Leonard, D., 2007. Conventional hydrothermal process versus microwave-assisted hydrothermal synthesis of $\mathrm{La1}_{-} \mathrm{xAgxMnO}_{-}+_{-}(\mathrm{x}=0,0.2)$ perovskites used in methane combustion. Comptes Rendus Chimie, 10(12), 1216-1226.

Islam, K.R., Weil, R.R., 1998. Microwave irradiation of soil for routine measurement of microbial biomass carbon. Biology and Fertility of Soils, 27, 408-416.

Jamali, M.K., Kazi, T.G., Arain, M.B., Afridi, H.I., Jalbani, N., Kandhro, G.A., Shah, A., Q., Baig, J.A., 2009. Specification of heavy metals in untreated sewage sludge by using microwave assisted sequential extraction procedure. Journal of Hazardous Materials, 16, 1157-1164.

Jimenez, B. 2007. Helminth Ova removal from wastewater for agriculture and aquaculture reuse. Water Science and Technology, 55 (1), 485-493.

Jonsson, H., Baky, A., Jeppsson, U., Hellstro mm, D., Ka ̈rrman, E., 2005. Composition of urine, faeces, greywater and biowaste for utilisation in the URWARE model. Urban Water Report 2005: 6.

Gothenburg: Chalmers University of Technology. 
Kappe, C.O., 2004. Controlled microwave heating in modern organic synthesis. Angew Chemie International Edition, 43(46), 6250-6284.

Kengne, I.M., Kengne, S.E., Akoa, A., Bemmo, N., Dodane, P-H., Koné, D., 2011. Vertical-flow constructed wetlands as an emerging solution for faecal sludge dewatering in developing countries. Journal of Water, Sanitation and Hygiene for Development 01(1), 13-19.

Khalil, H. and Villota, R., 1988. Comparative Study on Injury and Recovery of Staphylococcus Aureus Using Microwaves and Conventional Heating. Journal of Food Protection, 51, 181-186.

Kien, C., Cordano, A., Cook, D., Young, V., 1981. Fecal characteristics in healthy young adults consuming defined liquid diets or a free-choice diet. The American Journal of Clinical Nutrition, 34(3), 357-361.

Kirchmann, H., Pettersson, S., 1995. Human Urine - Chemical composition and fertiliser use efficiency. Fertiliser Research, 40, 149-154.

Kozempel, M.F., Annous, B.A., Cook, R.D., Scullen, O.J., Whiting, R.C. 1998. Inactivation of microorganisms with microwaves at reduced temperatures, Journal of Food Protection, 61, 582-585.

Kuo, C.Y., Wu, C.H, Lo, S.L., 2005. Removal of copper from industrial sludge by traditional and microwave Acid Extraction. Journal of Hazardous Materials, B120, 249-256.

Labuza, T.P., Baisier, W., 1992. Kinetics of nonenzymatic. In Physical Chemistry of foods.

Schwatzberg, H.G., Hartel, R.W. (Eds.), New York: Marcel Dekker, Inc.

Larhed, M., Moberg, C., Hallberg, A., 2002. Microwave-accelerated homogenous catalysis in organic chemistry. Accounts of Chemical Research, 35, 717-727.

Lee, I., Han, J-I., 2013. The effects of waste-activated sludge pretreatment using hydrodynamic cavitation for methane production. Ultrasonics Sonochemistry, 20, 1450 - 1455.

Lehmann, J., da Silva Jr., J.P., Steiner, C., Nehls, T., Zech, W., Glaser, B., 2003. Nutrient availability and leaching in an archaeological Anthrosol and a Ferrasol of the Central Amazon basin: fertilizer, manure and charcoal amendments. Plant and Soil, 249, 343-357.

Lentner, C., Wink, A., 1981. Units of Measurement, Body Fluids, Composition of the Body, Nutrition. Geigy Scientific Tables. Basle, Switzerland: Ciba-Geigy Ltd.

Li, Y.Y., Noike, T., 1992. Upgrading of anaerobic digestion of waste activated sludge by thermal pre-treatment. Water Science and Technology, 26, 857-866. 
Lian-hai, R., Yong-feng, N., Jian-guo, L., Yi-ying, J., Lu, S., 2006. Impact of hydrothermal process on the nutrient ingredients of restaurant garbage. Journal of Environmental Science, 18, 1012-1019.

Liao, P.H., Wong, W.T., Lo, K.V., 2005. Release of phosphorus from sewage sludge using microwave technology. Journal of Environmental Engineering and Science, 4, 77-81.

Libra, J.A., Ro, K.S., Kammann, C., Funke, A., Berge, N.D., Neubauer, Y., Titirici, M., Fuhner, C., Bens, O., Kern, J., Emmerich, K., 2011. Hydrothermal carbonization of biomass residuals: A comparative review of the chemistry, processes and applications of wet and dry pyrolysis. Biofuels 2(1), 89-124.

Loupy, A., 2002. Microwaves in Organic Synthesis. Weinheim: Wiley-VCH Verlag GmbH

Mai, V., McCrary, Q.M., Sinha, R., Glei, M., 2009. Associations between dietary habits and body mass index with gut micro biota composition and faecal water genotoxicity: An observational study in African American and Caucasian American volunteers. Nutrition Journal, 8, 49.

Martin, D.I., Margaritescu, I., Cirstea, E., Togoe, I., Ighigeanu, D., Nemtanu, M.R., Oproiu, C., Iacob, N., 2005. Application of accelerated electron beam and microwave irradiation to biological waste treatment. Vacuum, 77, 501-506.

Mazur, P., 1986. Causes of injury in frozen and thawed cells. Federation of American Societies for Experimental Biology, 24, Suppl. 15, S175-S182.

Menendez, J.A., Inguanzo, M., Pis, J.J., 2002. Microwave-induced pyrolysis of sewage sludge. Water Research, 36, 3261-3264.

Moore, J.G, Jessop, L.D., Osborne, D.N, 1987. Gas-Chromatographic and mass spectrometric analysis of the odour of human faeces. Gastroenterology, 93, 1321-13.

Mouneimne, A.H., Carrère, H., Bernet, N., Delgenès, J.P., 2003. Effect of saponification on the anaerobic digestion of solid fatty residues. Bioresource Technology, 90, 89 - 94.

Muspratt, A.M., Nakato, T., Niwagaba, C., Dione, C., Kang, J., Stupin, L., Regulinksi, J., Mbeguere, M., Strande, L. 2014. Fuel potential of faecal sludge: calorific value results from Uganda, Ghana and Senegal. Journal of Water, Sanitation and Hygiene for Development, 4(2), 223-230.

Nah, I.W., Kang, Y.W., Hwang, K.Y., Song, W.K., 2000. Mechanical pretreatment of waste activated sludge for anerobic digestion process. Water Research, 34, 2362 - 2368. 
Namioka, T., Moroshashi, Y., Yoshikawa, K., 2011. Mechanisms of malodour reduction in dewatered sewage sludge by means of the hydrothermal torrefaction. Journal of Environmental Engineering, 6, 119-130.

Newark, H.L., Lupton, J.R., 1990. Determinants and consequences of colonic luminal pH: Implications for colon cancer. Nutrition and Cancer, 14 (3-4), 161-173.

Niwagaba, C.B., Mbeguere, M., Strande, L., 2014. Faecal sludge quantification, characterisation and treatment objectives. In Faecal Sludge Management: Systems approach for implementation and operation. London: IWA Publishers.

Nwaneri, C., Foxon, K., Bakare, B., Buckley, C., 2008. Biological degradation processes within a pit latrine. In WISA 2008 Conference, 1, 18-22 May 2008, Sun City (p. 1). South Africa: Water Institute of Southern Africa (WISA).

Park, W.J., Ahn, H., Hwang, S., Lee, C.K., 2010. Effect of output power, target temperature and solid concentration on the solubilisation of waste activated sludge using microwave irradiation. Bioresource Technology, 101(1), 13-16.

Parshetti, G.K., Liu, Z., Jain, A., Srivivasan, M.P., Balasubramanian, R., 2013. Hydrothermal carbonisation of sewage sludge for energy production with coal. Fuel, 111, 201-210.

Penaud, V., Delgenes, J.P., Moletta, R., 2000a. Characterisation of soluble molecules from thermochemically pre-treated sludge. Journal of Environmental Engineering - ASCE, 126(5), 397402.

Perez Cid, B., Fernandez, A.A., Fernandez, G.E., Falque, L.E. 2001. Use of microwave single extractions for metal fractionation in sewage sludge samples. Analytica Chimica Acta, 431, 209_ 218.

Perez-Cid, B., Lavilla, I., Bendicho, C. 1999. Application of microwave extraction for partitioning of heavy metals in sewage sludge. Analytica Chimica Acta, 378, 201-210.

Peterson, A.A., Vogel, F., Lachance, R.P., Froeling, M., Antal, M.J., 2008. Thermochemical biofuel production in hydrothermal media: A review of sub-and supercritical water technologies. Energy Environment and Science, 1, 32-65.

Pino-Jelcic, S.A., Hong, S.M., Park, J.K., 2006. Enhanced Anaerobic Biodegradability and Inactivation of Faecal Coliforms and Salmonella spp. in Wastewater Sludge by using Microwaves. Water Environment Research, 78, 209-216. 
Polprasert, C., 1995. Organic waste recycling. London: John Wiley \& Sons Ltd.

Puschner Microwave Power Systems, 2016. Penetration Depths.

http://www.pueschner.com/en/microwave-technology/penetration-depths (accessed 06.06.16).

Putman, D. E., for NASA, 1971. Composition and concentrative properties of human urine. Report

Number: NASA CR-1802, Washington, DC.

Remya, N., Lin, J.G, 2011. Current status of microwave application in wastewater treatment - a review. Chemical Engineering Journal, 166 (3), 797-813.

Rose, C., Parker, B., Jefferson, B., Cartmell, A., 2015. The characterisation of Feces and urine: A review of the literature to inform advanced treatment technology. Critical reviews in Environmental Science and Technology, 45, 1827-1879.

Rulkens, W. 2008. Sewage Sludge as a Biomass Resource for the Production of Energy:

Overview and Assessment of the Various Options. Energy \& Fuels, 22, 9-15.

Sanin, F.D., Vesilind, P.A., Martel, C.J., 1994. Pathogen Reduction Capabilities Of Freeze/Thaw Sludge Conditioning. Water Research, 28 (11), 2393-2398.

Sato, H., Morimatsu, H., Kimura, T., Moriyama, Y., Yamashita, T., Nakashima, Y., 2002.

Analysis of malodorous substances in human faeces. Journal of Health Science, 48 (2), 179-185.

Schoenning, C., Stenstroem, T.A., 2004. Guidelines on the Safe Use of Urine and Faeces in Ecological Sanitation Systems. Stockholm Environment Institute (SEI), Stockholm: EcoSanRes Publication Series.

Schouwa, N.L., Danteravanichb, S., Mosbaeka, H., Tjella, J.C., 2002. Composition of human excreta - a case study from Southern Thailand. The Science of the Total Environment, 286, 155-166.

Show, K-T., Mao, T., Lee, D-J., 2007. Optimisation of sludge disruption by sonication. Water Research, 41, $4741-4747$.

Shuntaro, T., Jun-Ichi, A., 2011. Application of Microwave Technology for Utilization of Recalcitrant Biomass. In Advances in Induction and Microwave Heating of Mineral and Organic Materials. Grundas, Stannis (Ed.), InTech, DOI: 10.5772/14040

Smidt, E., Meissl, K., 2007. The applicability of FTIR in waste management. Waste Management, 27, 268-276.

Snyder, W., Cook, M., Tipton, I., Nasset, E., Karhausen, L., Howells, G., 1975. Reference man: 
Anatomical, physiological and metabolic characteristics. Report of Task Group on Reference ManInternational Commission on Radiological Protection. New York, NY: Pergamon Press.

Sobhy, A. and Chaouki, J., 2010. Microwave-assisted bio refinery. Chemical Engineering Transactions, 19, 25-30.

Speight, J.G., 2005. Handbook of coal analysis. New Jersey, USA: John Wiley \& Sons, Inc.

Spuhler, D., 2011. Dehydration and Storage. Sustainable sanitation and water management (SSWM).

www.sswm.info/content/dehydration-and-storage (accessed 08.06.2015)

Stephen, J.H., Cummings, A.M., 1980. The Microbial Contribution to Human Faecal Biomass. Journal of Medical Microbiology, 13(1), 45-56.

Strauss, M., 1985. Health aspects of nightsoil and sludge use in agriculture and aqua-culture. Part II: Pathogen survival (04/85). Duebendorf: International Reference Centre of Waste Disposal. Strauss, M., Montangero, A., 2002. Faecal Sludge Management: Review of practises, problems and initiatives. Dubendorf: EAWAG/SANDEC publications.

Stuckey, D.C., McCarty, P.L., 1978. Thermochemical pre-treatment of nitrogenous materials to increase methane yield. Biotechnology and Bioengineering Symposium, 8, 219-233.

Sun, X.H., Sumida, H., Yoshikawa, K., 2013. Effects of hydrothermal process on the nutrient release of sewage sludge. International Journal of W aste Resources, 3, 124.

Tchobanoglous, G., Barton, F., Stensel, H., 2003. Wastewater engineering treatment and reuse (4 ${ }^{\text {th }}$ ed.). New York: Metcalfe and Eddy.

Thostenson, E.T., Chou, T.W, 1999. Microwave processing: Fundamentals and applications. Composites: Part A, 30, 1055-1071.

Tian, Y., Zhang, J., Zuo, W., Chen, L., Cui, Y., Tan, T., 2013. Nitrogen conversion in relation to $\mathrm{NH} 3$ and HCN during microwave pyrolysis of sewage sludge. Environmental of Science and Technology, 47(7), 3498-3505.

Titley, J.G., Carey A.D., Crockett, G.M., Ham G.J., Harvey, M.P., Mobbs, S.F., Tournette, C., Penfold, J.S.S., Wilkins, B.T., 2000. Investigation of the sources and fate of radioactive discharges to public sewers. Environment Agency R\&D Technical Report P288. Environment Agency, UK 
Toreci, I., Kennedy, K.J., Droste, R.L, 2009. Evaluation of conitnuous mesophilic anaerobic sludge digestion after high temperature microwave pretreatment. Water Research, 43, 1273-1284.

Tyagi, V.K., Lo, S-L., 2011. Application of physico-chemical pretreatment methods to enhance the sludge disintegration and subsequent anaerobic digestion: an up to date review. Reviews in Environmental Science and Bio/Technology, 10, 215-242.

Tyagi, V.K., Lo, S-L., 2013a. Microwave irradiation: A sustainable way for sludge treatment and resource recovery. Renewable and Sustainable Energy Reviews, 18, 288-305

UNICEF for UN Inter-Agency Group for Child Mortality Estimation (IGME), 2012. Levels and Trends in Child Mortality Report, New York: UNICEF.

US Environmental Protection Agency (USEPA), 2003. Air Pollution Control Technology: Fact Sheet, EPA-452/F-03-022.

Venkatesh, M.S., Raghavan, G.S.V, 2004. An overview of microwave processing and dielectric properties of agro-food materials. Biosystems Engineering, 88(1), 1-18.

Vinnerås, B., Palmquist, H., Balmér, P., Weglin, J., Jensen, A., Andersson, Å., Jönsson, H., 2006. The characteristics of household wastewater and biodegradable waste - a proposal for new Swedish norms. Urban Water, 3, 3-11.

Volk, T., Rummel, J.D., 1987. Mass balances for a biological life support system simulation model. Advances in Space Research, 7(4), 141-148.

Von Spelling, M., 2007. Wastewater characteristics, treatment and disposal. Biological Wastewater Treatment Series, London: IWA Publishing.

Wahi, R., Idris, A., Salleh, M.A.M., Khalid, K., 2006. Low-temperature microwave pyrolysis of sewage sludge. International journal of Engineering and Technology, 3 (1), 132-138.

Wang, Y.-Z., Fu, Y., 2011. Microwave-hydrothermal synthesis and characterization of hydroxyapatite Nano crystallites. Materials Letters, 65 (23-24), 3388-3390.

WHO, 2003. Press release for World Environment Day. Geneva: WHO

WHO, 2006. Guidelines for the safe use of wastewater, excreta and greywater. Excreta and greywater use in agriculture, Volume 4, Geneva: WHO Publications.

WHO/UNICEF, 2004. Meeting the MDG drinking water and sanitation target: A mid-term assessment of progress. Geneva: WHO 
WHO/UNICEF, 2015. Progress on sanitation and drinking water- 2015 Update and MDG assessment. Geneva: WHO

Wierdsma, N.J., Peters, J.H.C., Weijs, P.J.M., Keur, M.B., Girbes, A.R.J., van Bodegraven, A.A., Beishuizen, A., 2011. Malabsorption and nutritional balance in the ICU: Fecal weight as a biomarker: A prospective observational pilot study. Critical Care, 15(6), R264.

Wignarajah, K., Litwiller, E., Fisher, J., Hogan, J., 2006. Simulated Human Faeces for Testing Human Waste Processing Technologies in Spaces Systems. SAE Technical Paper Series, 2006-012180. Proceedings of the 36th International Conference on Environmental Systems (ICES), 1720 July 2006, Norfolk, Virginia.

Wilson, C.A., Novak, J.T., 2009. Hydrolysis of macromolecular components of primary and secondary wastewater sludge by thermal hydrolytic pre-treatment. Water Research, 43, 4489-4498.

Wojciechowska, E., 2005. Application of microwaves for sewage sludge conditioning. Water Research, 39, 4749-4754.

Wong, W.T., Chan, W.I., Liao, P.H., Lo, K.V., Mavinic, D.S., 2006. Exploring the role of hydrogen peroxide in the microwave advanced oxidation process: solubilization of ammonia and phosphates. Journal of Environmental Engineering Science, 5, 459-65.

Wydeven, T., and Golub, M., 1991. Waste streams in a crewed space habitat. Waste Management \& Research, 9, 91-101.

Yadav, K.M., Tare, V., Ahmmed, M., 2010. Vermicomposting of source-separated human faeces for nutrient recycling. Waste Management, 30(1), 50-56.

Yeneneh, A. M., Kayaalp, A., Sen, T. K., Ang, H. M. 2015. Effect of microwave and combined microwave-ultrasonic pretreatment on anaerobic digestion of mixed real sludge. Journal of Environmental Chemical Engineering, 3(4), 2514-2521.

Yeneneh, A.M., Sen, T.K., Kayaalp, A., Ang, H. M. 2015. The Role of Sludge Pretreatment on the Enhancement of Anaerobic Digester Performance in Wastewater Treatment Plants, in Sen, T.K. (ed), Physical, Chemical and Biological Treatment Processes for Water and Wastewater. USA: Nova Publishers.

Yeom, I.T., Lee, K.R., Lee, Y.H., Ahn, K.H., Lee, S.H. 2002. Effects of ozone treatment on the biodegradability of sludge from municipal wastewater treatment plants. Water Science and Technology, 46, $421-425$. 
Yin, C., 2012. Microwave assisted pyrolysis of biomass for liquid biofuels production. Bioresource Technology, 120, 273-284.

Yoshida, T. and Antal, M.J., 2009. Sewage sludge carbonization for terra preta applications. Energy Fuels, 23, 5454-5459.

Yu, Q., Lei, H., Li, Z., Li, H., Chen, K., Zhang, X., Liang, R. 2010. Physical and chemical properties of waste-activated sludge after microwave treatment. Water Research, 44, 2841-2849.

Yu, Q., Lei, H., Yu, G., Feng, X., Li, Z., Wu, Z., 2009. Influence of microwave irradiation on sludge dewaterability. Chemical Engineering Journal, 155, 88-93.

Zheng, J., Kennedy, K. J., Eskicioglu, C. 2009. Effect of low temperature microwave pretreatment on characteristics and mesophilic digestion of primary sludge. Environmental Technology, 30, 319-327.

Zhenyu, L., Guangliang, X., Yalin, Z., 2007. Microwave assisted low temperature synthesis of MnZn ferrite nanoparticles. Nanoscale Research Letters, 2(1), 40-43.

Zhou, B. W., Shin, S. G., Hwang, K., Ahn, J-H., Hwang, S. 2010. Effect of microwave irradiation on cellular disintegration of Gram positive and negative cells. Applied Microbiology and Biotechnology, $87,765-770$.

Zupanc, M., KosjeK, T., Petkovšek, M., Dular, M., Kompare, B., Širok, B., Željko, B., Heath, E. 2013. Removal of pharmaceuticals from wastewater by biological processes, hydrodynamic cavitation and UV treatment. Ultrasonics Sonochemistry, 20, $1104-1112$. 